\title{
The AGMA1 poly(amidoamine) inhibits the infectivity of herpes simplex virus in cell lines, in human cervicovaginal histocultures, and in vaginally infected mice
}

\author{
Manuela Donalisio a , Paola Quaranta ${ }^{\text {b, c }}$, Flavia Chiuppesi ${ }^{\text {b }}$, Mauro Pistello ${ }^{\text {b }}$, \\ Valeria Cagno $^{\text {a }}$, Roberta Cavalli ${ }^{\mathrm{d}}$, Marco Volante ${ }^{\mathrm{e}}$, Antonella Bugatti ${ }^{\mathrm{f}}$, Marco Rusnati ${ }^{\mathrm{f}}$, \\ Elisabetta Ranucci ${ }^{\mathrm{g}}$, Paolo Ferruti ${ }^{\mathrm{g}}$, David Lembo ${ }^{\mathrm{a}}$ * \\ a Dipartimento di Scienze Cliniche e Biologiche, Università degli Studi di Torino, 10043 Orbassano, Torino, Italy \\ b Dipartimento di Ricerca Traslazionale e delle Nuove Tecnologie in Medicina e Chirurgia, Università di Pisa, 56126 Pisa, Italy \\ ${ }^{c}$ ARPA Foundation, 56126 Pisa, Italy \\ d Dipartimento di Scienza e Tecnologia del Farmaco, Università degli Studi di Torino, 10125 Torino, Italy \\ e Dipartimento di Oncologia, Università di Torino, 10043 Orbassano, Torino Italy \\ ${ }^{\mathrm{f}}$ Dipartimento di Medicina Molecolare e Traslazionale, Università di Brescia, 25123 Brescia, Italy \\ ${ }^{\mathrm{g}}$ Dipartimento di Chimica Organica e Industriale, Università degli Studi di Milano, 20133 Milano, Italy
}

\section{A R T I C L E I N F O}

\section{Article history:}

Received 17 November 2015

Received in revised form

15 January 2016

Accepted 26 January 2016

Available online 27 January 2016

\section{Keywords:}

Antiviral activity

Herpes simplex virus

Poly(amidoamine)

Attachment inhibitor

Microbicide

Sexually transmitted infections

\begin{abstract}
A B S T R A C T
The development of topical microbicides is a valid approach to protect the genital mucosa from sexually transmitted infections that cannot be contained with effective vaccination, like HSV and HIV infections. A suitable target of microbicides is the interaction between viral proteins and cell surface heparan sulfate proteoglycans (HSPGs). AGMA1 is a prevailingly cationic agmatine-containing polyamidoamine polymer previously shown to inhibit HSPGs dependent viruses, including HSV-1, HSV-2, and HPV-16. The aim of this study was to elucidate the mechanism of action of AGMA1 against HSV infection and assess its antiviral efficacy and biocompatibility in preclinical models. The results show AGMA1 to be a non-toxic inhibitor of HSV infectivity in cell cultures and human cervicovaginal histocultures. Moreover, it significantly reduced the burden of infection of HSV-2 genital infection in mice. The investigation of the mechanism of action revealed that AGMA1 reduces cells susceptibility to virus infection by binding to cell surface HSPGs thereby preventing HSV attachment. This study indicates that AGMA1 is a promising candidate for the development of a topical microbicide to prevent sexually transmitted HSV infections.
\end{abstract}

() 2016 Elsevier Ltd. All rights reserved.

\section{Introduction}

Herpes Simplex Viruses type 1 and 2 (HSV-1 and HSV-2) are closely related pathogens belonging to the Herpesviridae family of DNA viruses that cause a wide variety of clinical manifestations in humans: HSV-1 is more frequently associated with oral and labial lesions, whereas HSV-2 typically infects genital mucosa. However, both viruses can infect both oral and genital regions, and the incidence of genital infections, particularly those caused by HSV-1, are on the increase [1]. Following primary infection, HSVs establish

\footnotetext{
* Corresponding author. Department of Clinical and Biological Sciences, University of Torino, Regione Gonzole, 10, 10043 Orbassano, Turino, Italy.

E-mail address: david.lembo@unito.it (D. Lembo).
}

life-long latency in the neurons of the sensory ganglia proximal to the site of entry. Then, triggered by several viral and host factors, they periodically reactivate, descend into the primary site of infection, and replicate; leading to asymptomatic or symptomatic viral shedding [2]. Occasionally, HSV reactivation may result in lifethreatening infections of the central nervous system [3,4]. Both HSV-1 and HSV-2 infections are efficiently transmitted by sexual route and genital herpes is one of the most prevalent sexually transmitted infections (STIs) worldwide. Of note, genital ulcer disease, primarily associated with HSV-2 infection, increases the risk of HIV acquisition by damaging the genital mucosa; it induces local inflammation and the production of cytokines and chemokines that activate and recruit $\mathrm{CD} 4^{+}$HIV target cells [5-7].

Indeed, in resource-limited countries where both viruses are highly prevalent, a high proportion of HIV infections can be 
ascribed to a pre-existing HSV-2 infection [8,9]. Strategies that prevent or treat HSV infections are expected to reduce rates of the sexual transmission of HIV and should therefore be part of HIV-1 prevention programs [7,10-12]. At present, there are a number of antiviral medications with activity against HSV-1 and HSV-2 and all are nucleoside analogues. These include acyclovir, penciclovir and their derivates, valacyclovir, and famciclovir. However the effectiveness of antiviral therapy sometimes is limited by the development of antiviral resistance and relative high toxicity [13].

There are no vaccines currently available to prevent and treat HSV infection, but the pipeline is rich with candidates in various phases of development (for a comprehensive and update review see Ref. [14]) and studies directed at developing alternative approaches are underway; for instance, through the development of topical microbicides able to protect the genital mucosa from HSV (and HIV) acquisition and transmission. Easy-to-use microbicides, able to prevent most common sexually transmitted viruses, should be associated to PrEP strategy, that is mainly directed against HIV-1 and not able to prevent totally HSV infections [15].

On this regard, significant progresses to the development of effective microbicides against STI have been achieved with negatively charged polyanions and dendrimers of different formulations [16-20]. Unfortunately, most of these compounds did not pass phase III clinical trials and one, a dendrimer with highly anionic charged branches developed by Starpharma Pty Ltd (Melbourne, Australia) has proved active against bacterial vaginosis in humans and is currently under testing for efficacy against STIs in Phase 3 trials $[20,21]$.

Poly(amidoamine)s (PAAs) are a family of synthetic and highly biocompatible polymers with a highly versatile structure [22]. They are degradable polymers obtained by Michael-type polyaddition of primary or bis secondary amines to bisacrylamides. Many PAAs exhibit a combination of properties imparting them a considerable potential in the biomedical field. They are usually degradable in water at a rate depending on their structure. Therefore, if injected, they are bioeliminable [23]. Most PAAs are only moderately toxic despite their polycationic nature. According to a number of tests, the toxicity of most PAAs is significantly lower than that of poly-Llysine (PLL) or polyethylenimine (PEI) [24]. Amphoteric PAAs carrying side carboxyl groups switch from a prevailingly anionic to a prevailingly cationic state in a relatively small $\mathrm{pH}$ interval. Those that at pH 7.4 are prevailingly anionic proved nontoxic and nonhemolytic. By contrast, those that at the same $\mathrm{pH}$ are prevailingly cationic showed significant toxicity and hemolytic activity. An interesting exception is the PAA named AGMA1, prepared by polyaddition of monoprotonated (4-aminobutyl)guanidine (agmatine) to BAC. The repeating unit of AGMA1 contains three ionizable groups, a strong acid (pKa 2.3), a medium-strength base (pKa 7.4), and a strong base (pKa 12.1). AGMA1, an amphoteric, but prevailingly cationic polymer, proved nontoxic and nonhemolytic in vitro within the entire $\mathrm{pH}$ range tested (4.0-7.4) [25-27].

In a previous work, we screened a minilibrary of PAAs against a panel of DNA and RNA viruses to search for new antiviral chemical entities. AGMA1 selectively inhibited a panel of viruses, including HSV-1, HSV-2, and human papillomavirus-16 (HPV-16) [28], which exploit cell surface heparan sulfate proteoglycans (HSPGs) as attachment receptors. HSPGs consist of a protein core and glycosaminoglycan (GAG) side chains of unbranched sulfated polysaccharides, known as heparan sulfates, which are structurally related to heparin. The interaction between positively charged basic amino acids in HSV envelope and HPV capsid proteins and negatively charged sulfated/carboxyl groups of cellular HSPGs has been described $[29,30]$ and is considered an attractive target for the development of microbicides able to block infection by sexually transmitted viruses [16].
Polycationic dendrimers have been so far developed mainly for the transfection of genetic material into eukaryotic cells for gene therapy, an approach that has been found however to be burden by the tendency of these dendrimers to bind to glycosaminoglycans of the cells surface [31]. With these premises, some HSPG-targeting polycationic dendrimers have been developed and assayed in vitro against different viruses, showing promising features: the peptide dendrimer SB105-A10, containing clusters of basic amino acids, proved to be a potent inhibitor of cytomegalovirus [32], HSV1, HSV-2, a broad spectrum of genital HPV types, R5, and X4 HIV-1 and was found to exert its action mainly by binding to HS exposed on the cell surface [33-35]. Accordingly, we have recently demonstrated that AGMA1 interacts with immobilized heparin and cellular heparan sulfates, and that this, in turn, is able to prevent HPV attachment to the cell surface [36].

The aim of the present study was to elucidate the mechanism of action of AGMA1 against HSV infection and assess its antiviral potency and biocompatibility in preclinical models. The results show AGMA1 to be a non-toxic inhibitor of HSV infectivity in cell cultures and human-derived vaginal epithelium. Moreover, it significantly reduced the burden of infection of HSV-2 genital infection in mice.

\section{Materials and methods}

\subsection{Cells and viruses}

African green monkey kidney cells (Vero) (ATCC CCL-81) were purchased from American Type Culture Collection (ATCC; Manassas, VA). The culture medium was Eagle's minimal essential medium (E-MEM) (Gibco/BRL, Gaithersburg, MD) supplemented with heat-inactivated $10 \%$ fetal calf serum (FCS) (Gibco/BRL) and $1 \%$ antibiotic-antimycotic solution (Zell Shield, Minerva Biolabs GmbH, Berlin, Germany). The neurovirulent strains LV [37] and MS (ATCC VR-540) of HSV-1 and HSV-2, respectively, were used for most in vitro studies and all in vivo experiments. Both strains were sensitive to Acyclovir (ACV). Two laboratory HSV-2 strains (ACV-r1 and ACV-r2) with phenotypic resistance to ACV were generated by serial passage of the reference strain in the presence of increasing ACV concentrations. The fluorescence virus, HSV-1(GFP), encoding GFP fused to the gH envelope glycoprotein was kindly provided by Dr. E. Caselli, University of Ferrara, Italy. To generate viral stocks, semiconfluent T175 flasks of Vero cells were propagated in complete E-MEM and inoculated with $1 \mathrm{PFU} /$ cell of virus. After $6 \mathrm{~h}$, cells were fed with fresh E-MEM and cultured until cell lysis. Culture fluids were spun at $1200-\mathrm{g}$, and the pellets frozen-thawed three times to release intracellular virions. Supernatants were then clarified, pooled, and ultracentrifuged to concentrate the virus as previously described [38]. Pelleted virus was resuspended in $1 / 100$ of the initial volume in saline and stored in small aliquots at $-80^{\circ} \mathrm{C}$ until use. Viral titer of randomly picked frozen aliquots was determined in vitro by plaque assay on Vero cells.

\subsection{EpiVaginal ${ }^{\mathrm{TM}}$ tissues}

The EpiVaginal Tissue Model (VEC-100/VEC-100-FT) was purchased from MatTek Corporation (Ashland, MA, USA) and consists of Human 3-D Vaginal-Ectocervical Tissues cultured to form a multilayered and highly differentiated tissue closely resembling the epithelial architecture found in vivo. According to the supplier's instructions, EpiVaginal cultures were seeded with the apical surface exposed to air in 6-well plates containing $0.9 \mathrm{ml}$ MatTek assay medium (VEC-100-ASY) per well. Plates were incubated overnight at $37{ }^{\circ} \mathrm{C}$ in $5 \% \mathrm{CO}_{2}$. 


\subsection{Animals}

Inbred C57Bl/6 mice were purchased from Harlan Italy (Correzzana, Milan, Italy) and housed and bred in a Biosafety Level 3 animal facility approved for mice detention and reproduction. Mice were maintained on a 12/12 h dark/light cycle and handled according to European (2010/63/EU) and Italian (26/2014) guidelines. Since age and estrous cycle influence susceptibility to genital herpes and disease course [39], all in vivo experiments were carried out in mice of 11 weeks of age and with their estrous cycle synchronized with $2 \mathrm{mg}$ depot medroxyprogesterone acetate (Depo-Provera) inoculated subcutaneously 5 days before infection. All manipulations were performed under deep anesthesia with $2 \mathrm{ml} /$ hg 2,2,2-tribromoethanol inoculated intraperitoneally. The project was approved by the University of Pisa Ethical Committee for Animal Research.

\subsection{Reagents}

AGMA1 and biotinylated AGMA1(b-AGMA1) were prepared as reported elsewhere [28,36]. AGMA1 has an average molecular weight of 10,100 and a polydispersity of 1.25 . It is very soluble in water at all $\mathrm{pH}$ values, but hardly soluble in most organic solvents. It is amphoteric with isoelectric point 10.2. The pKa values of the carboxyl-, guanidine- and ter-amine- groups present in AGMA1 repeating unit are $2.25,7.4$ and $>12$, respectively. Therefore, in the $\mathrm{pH}$ interval 5-10 each unit carries both one positive and one negative charge, whereas the tert-amine group is $>90 \%$ protonated, that is, cationic at $\mathrm{pH} 6$ and approximately $50 \%$ protonated at $\mathrm{pH} 7.4$ [25-27,36]. Since AGMA1 is available in polydisperse preparations with an average molecular mass not unequivocally determinable, we quantitatively refer to the compound in $\mu \mathrm{g} / \mathrm{ml}$. Acyclovir (ACV), 2,2,2-tribromoethanol, gelatin, horseradish peroxidase-labeled streptavidin, methylcellulose, crystal violet, sodium dodecyl sulfate (SDS), NP-40, sodium deoxycholate, a cocktail of protease inhibitors, Tween 20, glycine and Triton X-100 were purchased from Sigma-Aldrich (Milan, Italy). Conventional heparin (13.6 kDa) was from Laboratori Derivati Organici S.p.A. (Milan, Italy). Heparinase II, a glycosidase that digests the GAG moiety of HSPGs [40] was from Sigma-Aldrich (St Louis, MO). Depot medroxyprogesterone acetate (Depo-Provera) was purchased from Pfizer Italia (Latina, Italy). Chromogenic substrate ABTS was from Kierkegaard \& Perry Laboratories (Gaithersburg, MD). The anti-HSV-1/2 ICP27 MAb (8.F.137B) and the anti-HSV-1 ICP8 MAb (clone 10A3) were from Abcam (Cambridge, UK). The anti-HSV-1/2 gD MAb (clone 2C10) was from Virusys Corporation (Taneytown, MD). The anti-actin MAb was from Chemicon International (Billerica, MA). The antimouse $\mathrm{Ab}$ conjugated to horseradish peroxidase, used in immunoblotting, was from Amersham Italia (Milan, Italy). The rabbit polyclonal anti-HSV-2 antibody and the biotin-free polymer-conjugated secondary antibody, used in immunohistochemistry, were from Dako (Glostrup, Denmark). Cyclophosphamide was purchased from Baxter (Rome, Italy). All the other reagents and solvents are commercially available and used as received.

\subsection{Preparation and characterization of AGMA1 solution}

To prepare the polymer solution, a weighed amount of AGMA1 was added to a $2.4 \%$ glycerol aqueous solution in water. The $\mathrm{pH}$ of the solution was corrected to 5.0 using a $0.1 \mathrm{M} \mathrm{NaOH}$. AGMA1 solution was characterized measuring osmolarity and viscosity values using a semi-micro osmometer K-7400 (Knauer) and a capillary viscosimeter (Ubeholde) respectively. These parameters were determined just prepared and after three months.

\subsection{Cell viability assay}

Confluent Vero cell cultures in 96-well plates were incubated with MTS [3-(4,5-dimethylthiazol-2-yl)-5-(3carboxymethoxyphenyl)-2-(4-sulfophenyl)-2H-tetrazolium] at different concentrations and in triplicate. Cells were cultured as for the in vitro antiviral assays and viability was determined using the CellTiter 96 Proliferation Assay Kit (Promega, Madison, WI, USA) according to the manufacturer's instructions. Absorbances were measured using a Microplate Reader (Model 680, BIORAD) at $490 \mathrm{~nm}$. The effect on cell viability of AGMA1 tested at different concentrations was expressed as a percentage, by comparing the absorbances of treated cells with those of cells incubated with culture medium alone. The $50 \%$ cytotoxic concentrations $\left(\mathrm{CC}_{50} \mathrm{~S}\right)$ and 95\% confidence intervals (CIs) were determined using Prism software (Graph-Pad Software, San Diego, CA).

\subsection{AGMA1 binding to Vero cells assays}

Monolayers of Vero cells in 96-well plates were incubated for $2 \mathrm{~h}$ at $4{ }^{\circ} \mathrm{C}$ in phosphate-buffered saline (PBS) containing $0.1 \mathrm{mg} / \mathrm{ml}$ $\mathrm{CaCl}_{2}, 0.1 \mathrm{mg} / \mathrm{ml} \mathrm{MgCl}_{2}$, and $0.1 \%$ gelatin, with sub-saturating concentrations of b-AGMA1 $(0.01 \mu \mathrm{g} / \mathrm{ml}$ or $0.1 \mu \mathrm{g} / \mathrm{ml})$ in the absence or presence of heparin $(10 \mu \mathrm{g} / \mathrm{ml})$. At the end of incubation, cells were washed with PBS, and the amount of cell-associated bAGMA1 was determined with horseradish peroxidase-labeled streptavidin (1/5000) and the chromogenic substrate ABTS. In some experiments, cell monolayers were washed with PBS containing $2 \mathrm{M} \mathrm{NaCl}$, a treatment known to remove cationic polypeptides from cell surface HSPGs [41]. Alternatively, cells were incubated with heparinase II $\left(15 \mathrm{mU} / \mathrm{ml}\right.$ ) for $1 \mathrm{~h}$ at $37{ }^{\circ} \mathrm{C}$ (an experimental condition demonstrated to efficiently remove HSPGs from the epithelial cells surface [36]) or left untreated before the binding assay.

\subsection{In vitro antiviral activity assays}

\subsubsection{HSV virus yield reduction assay}

The assay is finalized to quantify the antiviral effect of compound testing its effect on the production of infectious viruses. Vero cells were seeded in 24-well plates at a density of $10 \times 10^{4}$ cells/ well and infected in duplicate with HSV-1 or HSV-2 at a multiplicity of infection (MOI) of 0.01 plaque-forming units (PFU)/cell and in the presence of serial dilutions of the compound. Following adsorption at $37^{\circ} \mathrm{C}$ for $2 \mathrm{~h}$, the virus inoculum was removed and cultures were grown in the presence of AGMA1 until control cultures displayed extensive cytopathology. Supernatants were harvested and pooled as appropriate $48-72 \mathrm{~h}$ after infection and cell-free virus infectivity titers were determined in duplicate by plaque assay in Vero cell monolayers. The end-point of the assay was the effective concentration of compound that reduced virus yield by $50 \%\left(\mathrm{EC}_{50}\right)$ compared to untreated virus controls.

\subsubsection{HSV plaque reduction assay}

The assay is finalized to quantify the antiviral effect of compound testing its ability to reduce the number of viral plaques. Vero cells were seeded in 24 -well plates at a density of $10 \times 10^{4}$ cells/ well and infected at $0.001 \mathrm{MOI}$ in the presence of different concentrations of compound for $2 \mathrm{~h}$ at $37^{\circ} \mathrm{C}$, washed, and then overlaid with $1.2 \%$ methylcellulose. After $24 \mathrm{~h}$ (HSV-2) or $48 \mathrm{~h}$ (HSV-1) of incubation at $37^{\circ} \mathrm{C}$, cells were fixed and stained with $0.1 \%$ crystal violet in $20 \%$ ethanol and viral plaques were counted. The concentration of compound that reduced plaque formation by $50 \%$ (EC50) was determined by comparing treated and untreated wells. PRISM 4 software (GraphPad Software, San Diego, California, U.S.A.) was 
used to fit a variable slope-sigmoidal dose-response curve and calculate EC50 values. A selectivity index (SI) was calculated by dividing the $\mathrm{CC}_{50}$ by the $\mathrm{EC}_{50}$ value.

\subsubsection{Immunoblotting of viral proteins}

The assay is finalized to evaluate the ability of AGMA1 to inhibit the HSV-1 protein expression in treated-, infected-extracts of Vero cells. Whole-cell extracts were prepared by resuspending pelleted cells in lysis buffer containing $150 \mathrm{mM} \mathrm{NaCl}, 50 \mathrm{mM}$ Tris- $\mathrm{Cl}$ (pH 8), $0.1 \%$ SDS, $1 \%$ NP- $40,0.5 \%$ sodium deoxycholate and a cocktail of protease inhibitors. Soluble proteins were collected by centrifugation at $15,000 \mathrm{~g}$. Supernatants were quantified and stored at $-80^{\circ} \mathrm{C}$ as described [42]. For immunoblotting, proteins were separated by SDS-polyacrylamide gel electrophoresis (PAGE) and transferred to Immobilon-P membranes (Millipore). Membranes were then incubated with blocking buffer consisting of $5 \%$ nonfat dry milk in $10 \mathrm{mM}$ Tris-Cl (pH 7.5)-100 mM NaCl-0.1\% Tween 20 and immunostained with anti-HSV-1/2 MAbs against ICP27, ICP8 and gD proteins, and the anti-actin MAb. Immunocomplexes were detected using a sheep anti-mouse immunoglobulin $\mathrm{Ab}$ conjugated to horseradish peroxidase, and visualized using enhanced chemiluminescence (Super Signal; Pierce), according to the manufacturer's instructions.

\subsubsection{Virus inactivation assay}

The assay evaluates the virucidal activity of compound. AGMA1 (33 $\mu \mathrm{g} / \mathrm{ml}$ ) was added to aliquots of $10^{5}$ PFU HSV-1 or HSV-2 and incubated at either 4 or $37^{\circ} \mathrm{C}$ for $2 \mathrm{~h}$. After incubation, samples were titrated on Vero cells at high dilutions, at which the compound was not active.

\subsubsection{Cell pre-treatment assay}

The assay evaluates the antiviral activity of compound when administered before infection. Cells were exposed to different concentrations of AGMA1 in a 24 -well plate at $4{ }^{\circ} \mathrm{C}$ or $37^{\circ} \mathrm{C}$ for two hours. After washing, cells were infected with HSV-1 or HSV-2 at $0.001 \mathrm{MOI}$ for two hours, washed and treated as for plaque reduction assay.

\subsubsection{Attachment assay}

The assay evaluates the ability of compound to inhibit the attachment of virus to cells. The assay was performed as described previously [43]. Prechilled Vero cells were treated with AGMA1 or heparin for $30 \mathrm{~min}$ at $4{ }^{\circ} \mathrm{C}$ and then infected with HSV-1 or HSV-2 at $0.004 \mathrm{MOI}$ for $2 \mathrm{~h}$ at $4{ }^{\circ} \mathrm{C}$ in presence of the compound. After three washes with cold MEM to remove unbound virus, cells were overlaid with $1.2 \%$ methylcellulose and shifted to $37^{\circ} \mathrm{C}$. After $24 \mathrm{~h}$ (HSV-2) or $48 \mathrm{~h}$ (HSV-1) of incubation, cells were stained and viral plaques counted. Cells infected in absence of compound were arbitrarily set at $100 \%$ of infection and served as positive control. To examine viral attachment without entry, cells were incubated at $4{ }^{\circ} \mathrm{C}$ and treated for two minutes with cold acidic glycine (100 mM glycine, $150 \mathrm{mM} \mathrm{NaCl}, \mathrm{pH} 3$ ) to inactivate attached virus, resulting in $100 \%$ inhibition of infection.

\subsubsection{Entry assay}

The assay evaluates the ability of compound to inhibit the entry of virus into cells. HSV-1 or HSV-2 at $0.004 \mathrm{MOI}$ was adsorbed for $2 \mathrm{~h}$ at $4{ }^{\circ} \mathrm{C}$ on prechilled confluent Vero cells. Cells were then washed with cold MEM three times to remove unbound virus, treated with different concentrations of AGMA1 or Heparin, and incubated for three hours at $37^{\circ} \mathrm{C}$. Outer virions were inactivated with acidic glycine for $2 \mathrm{~min}$ at room temperature as described [43]. Cells were washed with warm medium three times and treated as for plaque reduction assay.

\subsubsection{Binding assay}

The assay evaluates the ability of compound to inhibit the binding of virus to cells. Cells were pre-incubated with AGMA1 or Heparin for $30 \mathrm{~min}$ or left untreated (control) at $4{ }^{\circ} \mathrm{C}$ and then infected for $2 \mathrm{~h}$ at $4{ }^{\circ} \mathrm{C}$ with 5 MOI HSV-1 as described [44]. Cells were then washed four times with PBS and lysed as described below in Immunoblotting section. HSV was detected with a MAb against the Glycoprotein D. Actin was stained as input control.

\subsubsection{Post-entry infection assay}

The assay evaluates the antiviral activity of compound when administered after infection. Vero cells monolayers in 96-well plate were infected with HSV- 1(GFP), HSV-1 or HSV-2 for two hours at $37{ }^{\circ} \mathrm{C}$, followed by two gentle washes to remove unbound virus. Increasing AGMA1concentrations (at $0 \mathrm{~h}$ post-infection) or $100 \mu \mathrm{g} /$ $\mathrm{ml}$ (at 1, 2, 3, 6 h post-infection) were then added to cultures in $1.2 \%$ methylcellulose medium. After incubation at $37^{\circ} \mathrm{C}$ for $24 \mathrm{~h}$ (HSV-2) or $48 \mathrm{~h}$ (HSV-1), cells were fixed and stained with $0.1 \%$ crystal violet in $20 \%$ ethanol to count the number and measure the size of viral plaques. Plaque size was measured with a Leica inverted microscope equipped with a Bresser MikroCam microscope camera and MikroCamLab software (Rhede, Germany). Plaques of HSV-1(GFP) were analyzed with an inverted Zeiss LSM510 fluorescence microscope and measured using with ImageJ software. To assess the effect of AGMA1 added after infection, a virus yield reduction assay was performed and $\mathrm{EC}_{50}$ determined by comparing drug-treated and untreated wells, as described above.

\subsection{Antiviral assay at acidic $\mathrm{pHs}$}

To evaluate the stability of AGMA1 at different pHs [45], the compound was incubated in phosphate-buffered saline solutions of $\mathrm{pH} 3, \mathrm{pH} 5, \mathrm{pH} \mathrm{7}$, for $2 \mathrm{~h}$ at $37{ }^{\circ} \mathrm{C}$ as previously described [45]. Thereafter, different concentrations of pH-treated AGMA1 were incubated with confluent Vero cell monolayers for $1 \mathrm{~h}$ at physiological $\mathrm{pH}$. Cells were then infected at physiological $\mathrm{pH}$ with HSV-2 at an MOI of 0.001 for two hours, washed and treated as for plaque reduction assay.

\subsection{Assays on EpiVaginal ${ }^{\mathrm{TM}}$ tissues}

\subsubsection{Viability assay}

EpiVaginal tissues were evaluated using the MTT ET-50 Tissue Viability Assay (MatTek Corporation), according to manufacturer's instructions. AGMA1 $(100 \mu \mathrm{g} / \mathrm{ml})$ was added to the cell culture insert placed on top of the EpiVaginal samples and incubated for $30 \mathrm{~min}, 1,4$, and $18 \mathrm{~h}$ in duplicate. At the end of incubation, any liquid remaining on top of the tissue was decanted and inserts were washed with PBS to remove any residual material. Tissues were then processed according to the MTT protocol and read at $570 \mathrm{~nm}$ using an ELISA plate. Tissues were incubated with $1.0 \%$ Triton X-100 and ultrapure water as positive and negative controls, respectively. The ET-50 value refers to the time required to reduce tissue viability to $50 \%$ and was determined using Prism software. According to the manufacturer an $\mathrm{ET}_{50}$ value $>18 \mathrm{~h}$ indicates that a compound does not cause vaginal irritation and can be used for feminine hygiene products.

\subsubsection{Cytotoxicity assay}

Any cytotoxic effect of AGMA1 $(100 \mu \mathrm{g} / \mathrm{ml})$ on EpiVaginal tissues was evaluated by analyzing the release of lactate dehydrogenase $(\mathrm{LDH})$ into culture medium, which increases in a manner that is proportional to the number of dead cells. The LDH cytotoxicity assay was performed according to manufacturer's protocol (TAKARA bio inc, Japan). 


\subsubsection{Analysis of inflammatory response}

This was evaluated by monitoring cytokine IL- $1 \alpha$ release into the culture medium of EpiVaginal tissues treated with AGMA1 $(100 \mu \mathrm{g} /$ $\mathrm{ml}$ ) for $30 \mathrm{~min}, 1,4$, and $18 \mathrm{~h}$, as previously reported [46]. After incubation, the concentration of IL- $1 \alpha$ in the culture medium was measured using the IL-1 alpha ELISA KIT, according to the manufacturer's instructions (Bender Medsystem). The concentration of IL- $1 \alpha$ was calculated by interpolation from a standard calibration curve.

\subsubsection{Antiviral assays}

EpiVaginal Tissue cultures were pre-incubated with $100 \mu \mathrm{l}$ medium containing $100 \mu \mathrm{g} / \mathrm{ml}$ AGMA1. Medium was applied to the apical surface and cells were incubated at $37^{\circ} \mathrm{C}$ for $2 \mathrm{~h}$. After preincubation, the medium was removed and cultures were infected with $1000 \mathrm{pfu} \mathrm{HSV}-2$ at $37{ }^{\circ} \mathrm{C}$ for $2 \mathrm{~h}$ in the presence of AGMA1. Cultures were washed apically with $100 \mu \mathrm{l}$ medium, incubated at $37{ }^{\circ} \mathrm{C}$, and fed each day via the basolateral surface with $0.9 \mathrm{ml}$ medium. Viruses were harvested at 24, 48, 72 and 96 hpi by adding $100 \mu \mathrm{l}$ medium per well to the EpiVaginal Tissue apical surface that was allowed to equilibrate for $30 \mathrm{~min}$. Viral suspension was then collected and stored at $-80{ }^{\circ} \mathrm{C}$ until viral titers were determined by plaque assay in Vero cell monolayers. Harvesting was performed daily.

\subsubsection{Detection of HSV-2 by immunohistochemistry}

HSV-2 was detected on EpiVaginal cultures by immunohistochemistry using a polyclonal anti-HSV-2 antibody. Briefly, EpiVaginal tissue cultures were fixed in buffered formalin, properly oriented, and embedded in paraffin together with adherent collagen membranes. Tissue sections were incubated with the antiHSV-2 antibody or stained with hematoxylin and eosin. Tissues were processed for antigen retrieval in citrate buffer using a dedicated pressure cooker ( 1 cycle for $5^{\prime}$ at $125{ }^{\circ} \mathrm{C}$, followed by $10 \mathrm{~s}$ at $90^{\circ} \mathrm{C}$ ). After incubation with the primary antibody (1:500 dilution), the reaction was visualized using a biotin-free polymer-conjugated secondary antibody. In positive samples, the antibody showed cytoplasmic and nuclear immunoreactivity, mostly recognizable in cells of the superficial layers. Several sections were analyzed for each experimental condition.

\subsection{Analysis of antiviral activity in vivo}

\subsubsection{Titration of viral stocks in vivo}

All animals were treated in parallel and grouped at random. Eleven-week-old mice were infected via vagina following estrous cycle synchronization. To facilitate absorption, vaginas were preswabbed with a dry tipped swab immediately prior to instillation of 10 -fold dilutions of viral stocks. Animals were then examined daily for clinical signs of infection that were graded according to a five-point scale: 0 , no signs; 1 , slight genital erythema and/or edema; 2, papules, ulcers and/or swelling; 3 , fused ulcers, purulent genital lesions and/or hind limb paralysis; 4, death [47]. Titrations were performed using 5-8 animals/virus dilution. Lethal dose 50\% (LD50) was calculated using the Reed-Müench method. One and 10 $\mathrm{LD}_{50}$ roughly corresponded to $10^{6}$ and $10^{8} \mathrm{PFU}$, respectively. Animals that survived despite paralysis or other irreversible lesions were euthanized by cervical dislocation under anesthesia.

\subsubsection{Analysis of AGMA1 efficacy}

The antiviral activity of AGMA1 against HSV-1 and HSV-2 vaginal infections was assessed by dispensing AGMA1 $(1 \mathrm{mg} / \mathrm{ml})$ in a $2.4 \%$ glycerol aqueous solution, as described previously. AGMA1 $(10 \mu \mathrm{l})$ was applied to pre-swabbed vaginas at varying time-points prior to infection (15s-30 min). The "Vehicle" group, referring to the glycerol aqueous solution used to prepare the AGMA1 solution, was treated the same way. Infections were performed with 1,10 and $100 \mathrm{LD}_{50}$. Animals were monitored for clinical signs of infection for about 4 weeks post-infection. Immunosuppression was achieved with an intraperitoneal bolus of $350 \mathrm{mg} / \mathrm{kg}$ cyclophosphamide that depleted the circulating lymphocytes in a mouse by approximately $90 \%$ within 1 day, as described [38].

\subsubsection{Detection of HSV-2 DNA genome in nervous tissues}

Sacral nerves and genital ganglia were protease digested and the DNA extracted using the QIAamp DNA mini kit, as recommended by the manufacturer (Qiagen, Milan, Italy). Molecular analysis was carried out by performing a HSV-2 specific nested polymerase chain reaction (PCR) as previously described [48]. The outer and inner PCR primer pairs were: forward 6AF (5'-TCAGCCCATCCTCCTTCGGCAGTA- $\left.3^{\prime}\right)$ - reverse 6BR (5'-GATCTGGTACTCGAATGTCTCCG $\left.-3^{\prime}\right)$ and forward 6CF $\left(5^{\prime}\right.$ AGACGTGCGGGTCGTACACG-3' $3^{\prime}$ - reverse 6DR (5'CGCGCGGTCCCAGATCGGCA-3'), respectively. The amplification profile (denaturation: $94{ }^{\circ} \mathrm{C}$ for $2 \mathrm{~min}$; cycling: $94{ }^{\circ} \mathrm{C}$ for $1 \mathrm{~min}$, $56{ }^{\circ} \mathrm{C}$ for $1 \mathrm{~min}$, and $72{ }^{\circ} \mathrm{C}$ for $1 \mathrm{~min}-5$ cycles; cycling: $94^{\circ} \mathrm{C}$ for $45 \mathrm{~s}$, $56{ }^{\circ} \mathrm{C}$ for $30 \mathrm{~s}, 72{ }^{\circ} \mathrm{C}$ for $1 \mathrm{~min}-40$ cycles; final extension $72{ }^{\circ} \mathrm{C}$ for $15 \mathrm{~min}$ ) was the same for both PCRs except that the second amplification profile was diminished from 40 to 30 cycles. Amplicons were examined by agarose gel (1\%) electrophoresis.

\subsection{Statistical analysis}

All data were analyzed using GraphPad Prism 5.00 (GraphPad Software). Infectivity and measurement of plaque sizes in the presence and absence of AGMA1 were compared by one-way analysis of variance (ANOVA) followed by a Bonferroni test if $P$ values showed significantly differences. Results were expressed as means \pm standard deviations. Results of the direct binding test of the compound to the cell surface, were analyzed by Student's t test. The Fisher exact test was applied to evaluate the in-vivo test results. Differences in number of disease-free animals of AGMA1 vs vehicle and naïve groups were assessed for statistical significance using heterogeneity of contingency tables. A value of $p<0.05$ was considered significant.

\section{Results}

\subsection{AGMA1 solution characterization}

The AGMA1 solution showed a $\mathrm{pH}=5.0$, a viscosity $=1.07 \mathrm{cP}$ and an osmolarity $=340 \mathrm{mOs}$, values suitable for a vaginal application. These parameters did not change after three months from the preparation.

\subsection{Antiviral activity of AGMA1 against HSV-1, HSV-2, and $A C V-$ resistant strains in vitro}

AGMA1 was evaluated in vitro for antiviral activity against HSV1, HSV-2, and two HSV-2 ACV-resistant strains by plaque reduction assays. Assays were performed by incubating cells in the presence of decreasing concentrations of compound (ranging from $100 \mu \mathrm{g} /$ $\mathrm{mL}$ to $0.13 \mu \mathrm{g} / \mathrm{mL}$ ) during and after viral adsorption. As shown in Table 1, AGMA1 was active against wild-type HSV-1 and HSV-2 with $\mathrm{EC}_{50}$ values of 3.05 and $1.3 \mu \mathrm{g} / \mathrm{ml}$, respectively, similar to previously reported values [28]. As expected, the resistant strains exhibited elevated $\mathrm{EC}_{50}$ s for ACV [260 $\mu \mathrm{M}$ and $319 \mu \mathrm{M}(58.5 \mu \mathrm{g} / \mathrm{ml}$ and $71 \mu \mathrm{g} / \mathrm{ml}$ ), respectively (data not shown in Table 1)]. By contrast, they were susceptible to AGMA1 inhibitory activity. Microscopic inspection and cell viability assays showed that 
Table 1

AGMA-1 antiviral activity against wild-type and ACV resistant HSV strains.

\begin{tabular}{llll}
\hline Virus & $\mathrm{EC}_{50}{ }^{\mathrm{a}}(\mu \mathrm{g} / \mathrm{ml})$ & $\mathrm{CC}_{50}{ }^{\mathrm{a}}(\mu \mathrm{g} / \mathrm{ml})$ & $\mathrm{SI}^{\mathrm{b}}$ \\
\hline HSV-1 & $3.05 \pm 1.22$ & $>300$ & $>98.36$ \\
HSV-2 & $1.30 \pm 1.15$ & $>300$ & $>230.76$ \\
HSV-2 ACV-r1 & $0.69 \pm 1.34$ & $>300$ & $>434.78$ \\
HSV-2 ACV-r2 & $1.00 \pm 1.98$ & $>300$ & $>300.00$ \\
\hline
\end{tabular}

a ${ }^{\text {The }} \mathrm{EC}_{50}$ (effective compound concentration that reduced viral plaque formation by $50 \%$ ) and the $\mathrm{CC}_{50}$ ( $50 \%$ cytotoxic concentration) are expressed as the mean $(\mu \mathrm{g} / \mathrm{ml}) \pm$ S.D. of three independent experiments.

${ }^{\mathrm{b}} \mathrm{SI}=$ selectivity index, determined by the ratio of $\mathrm{CC}_{50}$ to $\mathrm{EC}_{50}$.

AGMA1 was not toxic to Vero cells up to the highest concentration tested $(300 \mu \mathrm{g} / \mathrm{ml})$, demonstrating that the antiviral activity was not a consequence of cell toxicity.

The antiviral effect of AGMA1 was confirmed further by means of the yield reduction assay (see Materials and Methods section), a stringent test that allows multiple cycles of viral replication to occur before measuring the production of infectious viruses. The dose-response curves reported in Fig. 1 show that AGMA1 effectively reduces the HSV-1 and HSV-2 yield, with $\mathrm{EC}_{50}$ values equal to $0.74 \mu \mathrm{g} / \mathrm{ml}$ and $1.14 \mu \mathrm{g} / \mathrm{ml}$, respectively.

\subsection{Investigation of AGMA1 mechanism of action}

AGMA1's activity against ACV-resistant strains, as summarized in Table 1, may suggest that AGMA1 acts through a different mechanism of action to that of ACV. To substantiate this hypothesis, the effect of AGMA1 and ACV on the expression of immediate-early, early and late viral proteins (ICP27, ICP8, and gD, respectively) was investigated by western blotting. As shown in Fig. 2, ACV completely suppressed the expression of the late protein $\mathrm{gD}$. This finding was expected as ACV is a known inhibitor of viral replication, an event that occurs prior to late gene expression. In contrast, in addition to gD, AGMA1 also completely inhibited the expression of early viral proteins, indicating that AGMA1 may either inactivate the virus particle or inhibit an early step of the viral replication cycle that immediately precedes early gene expression (i.e. virus attachment or entry).

We first investigated whether the antiviral action of AGMA1 is exerted via the direct inactivation of HSV-1 or HSV-2 virus particles. To this end, we performed the virus inactivation assay described in

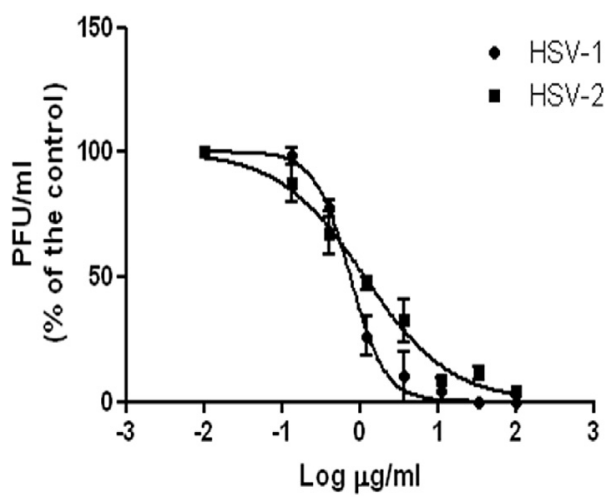

Fig. 1. AGMA1 reduces virus yield in Vero cells. Vero cells were infected at a MOI of 0.01 with clinical isolates of HSV-1 or HSV-2 and treated with increasing doses of AGMA1 during viral adsorption. Cells were exposed to the drug concentrations until an extensive viral cytopathic effect was observed in the untreated controls. The supernatants from cell suspensions were assayed for their infectivity by standard plaque reduction assay. Values are the means \pm SD of three separate experiments performed in duplicate.

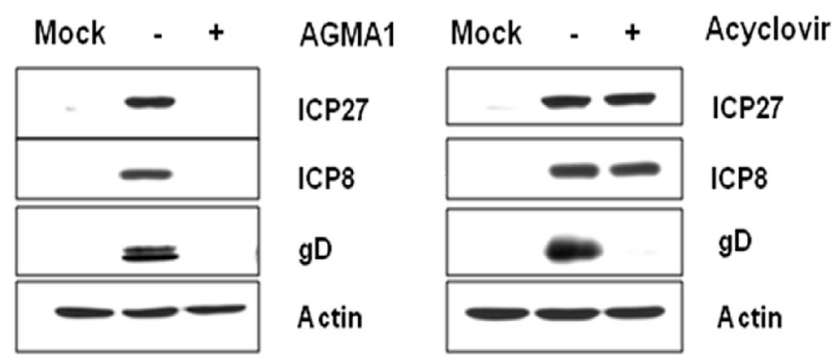

Fig. 2. AGMA1 inhibits early and late HSV gene expression. Vero cells were infected with HSV-1 in the absence or presence of AGMA1 or Acyclovir during infection. Mock: uninfected cells. Proteins were extracted and analyzed by western blotting using the following antibodies: anti-ICP27, anti-ICP8, and anti-gD. Actin served as an internal control.

section 2.8.4. As reported in Table 2, the virus titers of samples treated with AGMA1 did not significantly differ from those determined for untreated samples $(P<0.05)$, indicating that the compound does not inactivate extracellular virus particles.

Next, we investigated whether AGMA1 could interfere with the early stages of viral infection. In a first series of experiments, the viral attachment assays described in section 2.8.6. were performed. As shown in Fig. 3A, under these experimental conditions AGMA1 inhibited HSV1 and HSV-2 infection with $\mathrm{EC}_{50} \mathrm{~S}(3.09 \mu \mathrm{g} / \mathrm{ml}$ and $5.66 \mu \mathrm{g} / \mathrm{ml}$, respectively) that are comparable to those measured in the classic viral plaque assay suggesting that the antiviral activity of AGMA1 depends on its capacity to inhibit the attachment of the viruses to the cell surface. To substantiate this interpretation, cells from the attachment assay were lysed after washing and processed for immunoblotting, performed using a MAb directed against the viral glycoprotein $\mathrm{gD}$, to detect the amount of viral particles bound to the cell surface. Heparin was used in this assay as a positive control, being a known inhibitor of HSV attachment, which acts by competing with cell-surface HSPGs for virus binding [49,50]. As reported in Fig. 3B, both AGMA1 and heparin inhibited HSV-1 infection. In a second series of experiments, we explored the ability of AGMA1 to prevent HSV entry using the entry assay described at section 2.8.7. As reported in Fig. 3A, AGMA1 did not affect the capacity of prebound HSV-1 or HSV-2 virus to infect cells at any dose examined. Taken together, these data indicate that AGMA1 does not inactivate HSV-1 or HSV-2; instead it acts by inhibiting virus attachment, but not entry.

Antiviral compounds that block virus attachment to target cells mainly act by binding to (and sequestering) virions in the extracellular environment [16] or by binding (and masking) virus receptors on the surface of target cells [33]. To explore the possibility that AGMA1 acts directly on Vero cells, the pre-treatment assay described at section 2.8.5. was performed. As reported in Fig. 4, AGMA1 inhibited infection by both HSVs in a dose response

Table 2

Effect of AGMA1 on virus infectivity.

\begin{tabular}{|c|c|c|c|c|}
\hline \multicolumn{2}{|c|}{ Incubation condition } & \multirow[t]{2}{*}{$\mathrm{AGMA}^{\mathrm{a}}$} & \multicolumn{2}{|c|}{ Virus titer $(\mathrm{PFU} / \mathrm{ml})^{\mathrm{b}}$} \\
\hline Temp $\left({ }^{\circ} \mathrm{C}\right)$ & $\overline{\text { Duration }(\mathrm{h})}$ & & HSV-1 & HSV-2 \\
\hline 37 & 0 & - & $4.00 \times 10^{5}$ & $1.19 \times 10^{5}$ \\
\hline 37 & 0 & + & $3.30 \times 10^{5}$ & $1.68 \times 10^{5}$ \\
\hline 37 & 2 & - & $4.19 \times 10^{4}$ & $4.50 \times 10^{4}$ \\
\hline 37 & 2 & + & $3.70 \times 10^{4}$ & $3.54 \times 10^{4}$ \\
\hline 4 & 2 & - & $6.02 \times 10^{5}$ & $1.57 \times 10^{5}$ \\
\hline 4 & 2 & + & $9.24 \times 10^{5}$ & $9.82 \times 10^{5}$ \\
\hline
\end{tabular}

a Concentration: $33 \mu \mathrm{g} / \mathrm{ml}$.

b Virus titers at high dilutions at which the compound was not active. The titers are mean values for experiments performed in triplicate. 
A

HSV-1
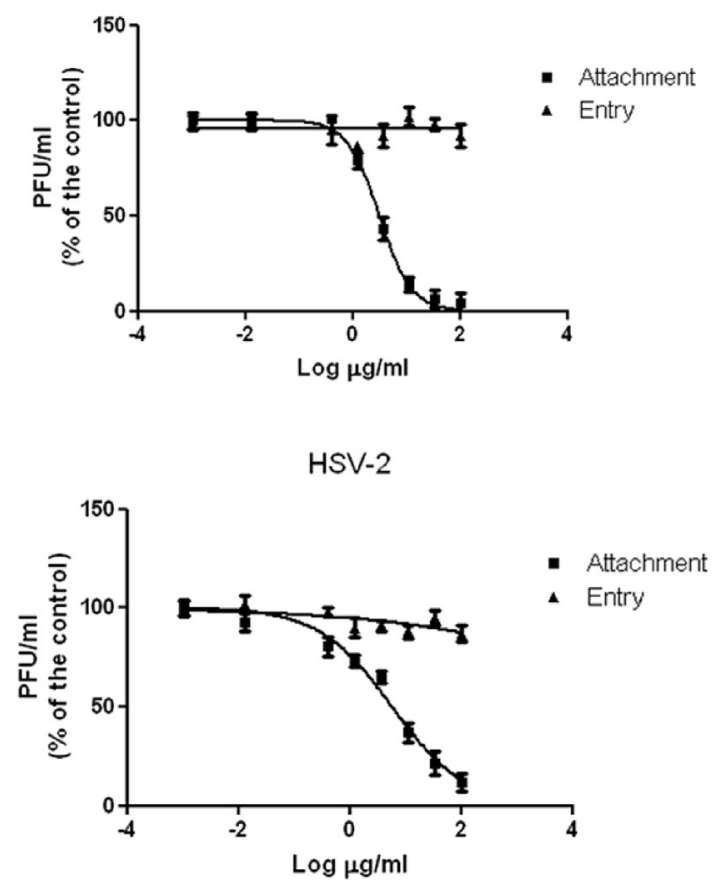

B

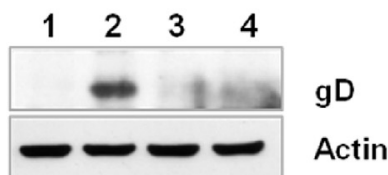

Fig. 3. AGMA1 prevents attachment but not entry of HSV to target cells. (A) Anti-HSV1 activity and anti-HSV-2 activity in attachment and entry assays by Plaque Reduction Assay. Attachment: cells were pretreated with AGMA1 for 30 min at $4{ }^{\circ} \mathrm{C}$ and then infected for $2 \mathrm{~h}$ at $4{ }^{\circ} \mathrm{C}$. Entry: prechilled cells were infected with viruses for $2 \mathrm{~h}$ at $4{ }^{\circ} \mathrm{C}$, then washed and treated with AGMA1 for $3 \mathrm{~h}$ at $37^{\circ} \mathrm{C}$; unpenetrated virions were inactivated by acidic glycine treatment. Values are the means \pm SD of three separate experiments performed in duplicate. (B) Binding assay: cells were preincubated with AGMA1 or heparin $(100 \mu \mathrm{g} / \mathrm{ml})$ for $30 \mathrm{~min}$ and then infected at an MOI of 5 with HSV-1 for $2 \mathrm{~h}$. Columns: (1) uninfected; (2) infected; (3) infected in presence of heparin; (4) infected in the presence of AGMA1. Attached virions were detected by Immunoblotting, using a Mab directed against the glycoprotein gD. Actin served as an internal control. manner with $\mathrm{EC}_{50}$ s equal to $1.54 \mu \mathrm{g} / \mathrm{ml}$ and $2.14 \mu \mathrm{g} / \mathrm{ml}$ for $\mathrm{HSV}-1$ and HSV-2, respectively. As expected, heparin (that acts by binding directly to the virus) was inactive under these experimental condition. Taken together, these data suggest that AGMA1 reduces cells susceptibility to virus infection by tethering to the cell surface and possibly masking HSV receptors.

\subsection{AGMA1 interacts with the cell surface via HSPGs}

Based on the above results we investigated the effective capacity of AGMA1 to bind to the cell surface of Vero cells via HSPGs (see methods, paragraph 2.7). As shown in Fig. 5A, AGMA1 effectively binds to the surface of Vero cells in a dose-dependent and saturable manner. Moreover, binding could be disrupted by washing with $2 \mathrm{M} \mathrm{NaCl}$ (a treatment known to disrupt the binding of cationic molecules to HSPGs [41]) and it could be prevented by a molar excess of heparin (a structurally related antagonist of HSPGs) and by cell treatment with heparinase (an enzyme that removes the heparan sulfate chains from cell surface-associated HSPGs) (Fig. 5B). Taken together, these results provide strong evidence that AGMA1 interacts with the cell surface via HSPGs. However, the partial inhibition of AGMA1 binding to heparinase II-treated cells also suggest that other receptors beside HSPG may bind AGMA1.

\subsection{Effect of AGMA1 on the cell-to-cell spread of HSV}

To determine whether AGMA1 interferes with cell-to-cell virus spreading, post-entry assays, described at section 2.8.9., were performed. As shown in Fig. 6A, the area of HSV-1(GFP) plaques, assessed by fluorescence microscopy, decreased in a dosedependent manner in AGMA1-treated cells, and at a concentration of $100 \mu \mathrm{g} / \mathrm{ml}$ singly infected cells were mainly seen. In contrast to the significant reduction in plaque size, quantified using ImageJ software, no significant reduction in the number of HSV plaques was observed. Similar results were obtained for wild-type HSV-1 (Fig. 6B) and HSV-2 (Fig. 6C). A process of fusion of plasma membrane of an infected cell with that of a neighboring uninfected cell, is thought to occur during cell-to-cell spread. Recently, syndecans, single transmembranous heparan sulfate proteoglycans, have been demonstrated to contribute to HSV-1 induced cell-to-cell fusion and lateral spread [51]. Inhibition of cell-to-cell spread of HSV by AGMA1, it's probably due to its ability to interact with HSPG and consequently mask the core protein of syndecan-1, involved in membrane fusion. Viral yield reductions assays also demonstrated that addition of AGMA1 after infection heavily affected viral pro-
HSV-1

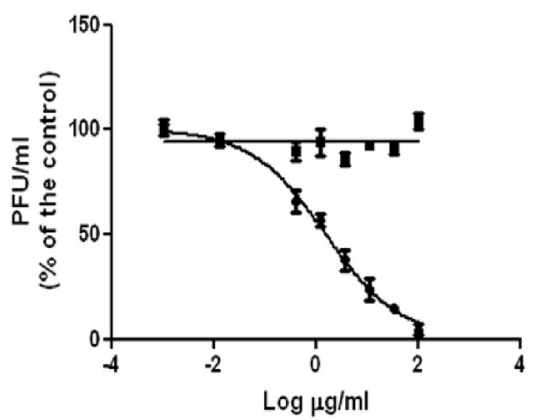

HSV-2

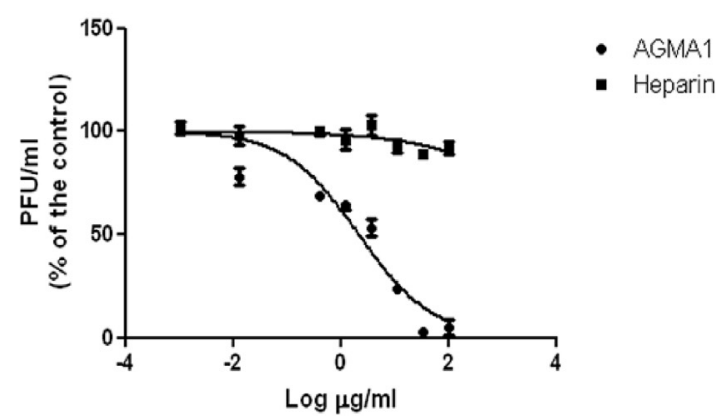

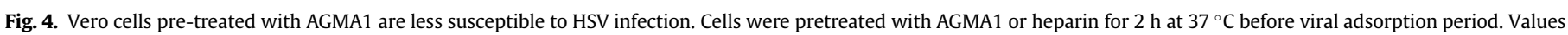
are the means \pm SD of three separate experiments performed in duplicate. 

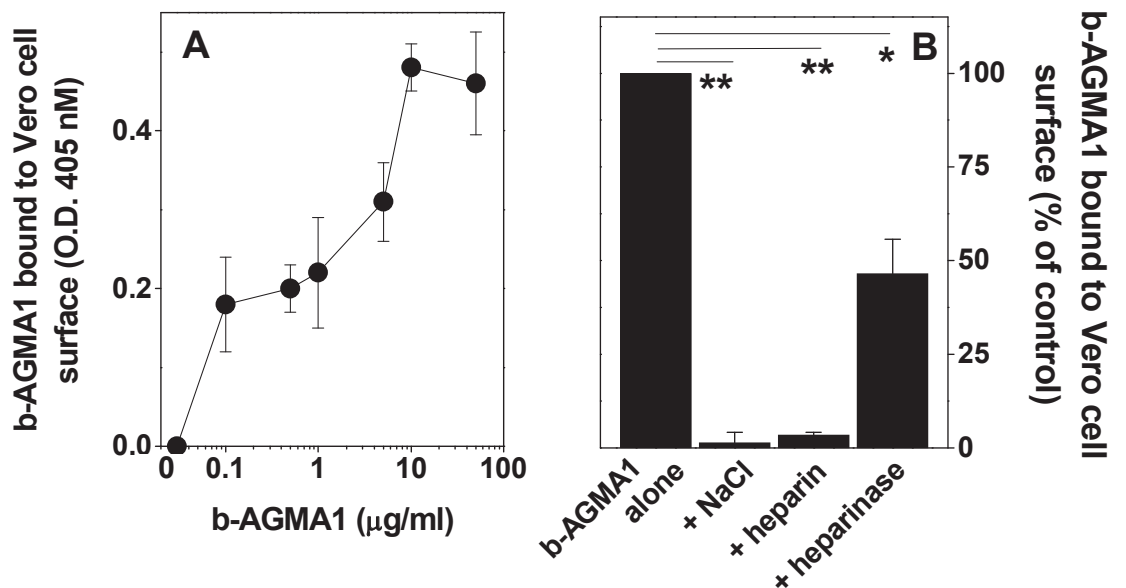

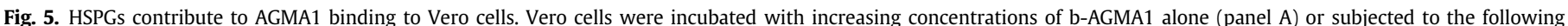

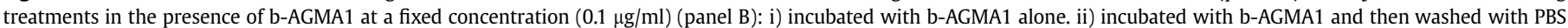

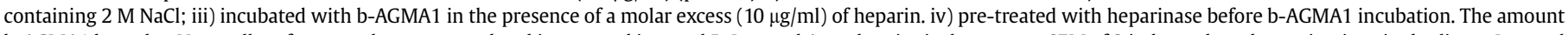

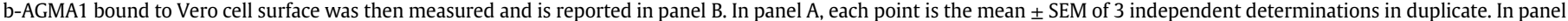

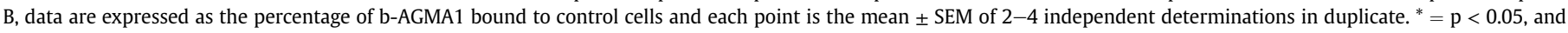
${ }^{* *}=\mathrm{p}<0.01$ with respect to control treated with b-AGMA1 alone, Student's $t$ test.

duction (data not shown) with EC50s of $6.54 \mu \mathrm{g} / \mathrm{ml}$ (HSV-1) and $3.98 \mu \mathrm{g} / \mathrm{ml}$ (HSV-2).

\subsection{AGMA1antiviral activity is not affected by acidic $p H s$}

Analysis of the mechanism of action of AGMA1 demonstrated its ability to prevent HSV infection. To evaluate its potential as candidate microbicide for preventing genital HSV-2 infections, the antiviral activity in presence of specific physiological properties of the vagina, such as acidic pHs, was considered. To this end, AGMA1 was incubated in buffers of different pHs for $2 \mathrm{~h}$ at $37{ }^{\circ} \mathrm{C}$, and the antiviral activity was evaluated by viral plaque reduction assays at physiological pH. Results demonstrated that the acidic treatment did not affect the activity of AGMA1, since the inhibitory effect against $\mathrm{HSV}-2$ at $\mathrm{pH} 3\left(\mathrm{EC}_{50}: 3.86 \mu \mathrm{g} / \mathrm{ml}\right)$ and at $\mathrm{pH}_{5}\left(\mathrm{EC}_{50}: 2.28 \mu \mathrm{g} /\right.$ $\mathrm{ml}$ ) was similar to that observed for compound incubated at neutral $\mathrm{pH}\left(\mathrm{EC}_{50}: 2.32 \mu \mathrm{g} / \mathrm{ml}\right)$.

\subsection{Antiviral activity of AGMA1 in EpiVaginal tissue}

To investigate the effects of AGMA1 in a model that more closely resembles the in vivo environment, the EpiVaginal system was employed. Briefly, this system consists of human-derived ectocervical epithelial cells grown on a collagen-coated membrane to form a multilayered and highly differentiated tissue that closely resembles the vaginal mucosa. EpiVaginal cultures were treated apically with $100 \mu \mathrm{g} / \mathrm{ml}$ AGMA1 for two hours, and then infected with 1000 pfu HSV-2. AGMA1 totally inhibited the virus emerging from the apical surface at different days post infection (Fig. 7A). Complete inhibition of viral infection was confirmed by immunohistochemistry, using an HSV-2-specific antibody, at 3 days postinfection. As shown in Fig. 7B, sections derived from the infected tissue exhibited strong staining for the expression of HSV-2 antigens (Fig. 7Bb). In contrast, no HSV-2 positive cells were observed in the uninfected tissue (Fig. 7Ba). AGMA1-treated samples did not show a HSV-2 signal (Fig. 7Bc). In addition, pre-treatment of tissues with AGMA1 reduced viral infection at 2 days post infection $(84 \%$ inhibition; data not shown).

Since reconstituted tissues are ideally suited for toxicology studies [52], we also tested biocompatibility and the inflammatory potential of AGMA1. Briefly, AGMA1 $(100 \mu \mathrm{g} / \mathrm{ml})$ was applied to the apical surface at the air-tissue interface for 1,4 , or $18 \mathrm{~h}$ at $37^{\circ} \mathrm{C}$, and tissues were subsequently analyzed for (i) the reduction of tetrazolium salt (MTT) to colored formazan compounds in order to study the metabolic activity of the living cells; (ii) lactate dehydrogenase (LDH) release, to measure the accumulation of dead cells; and (iii) the release of interleukin-1 alpha (IL-1 alpha) to evaluate the inflammatory activation of cells (see Materials and Methods for further details). As reported in Table 3, AGMA1 did not affect viability, and Effective-Time 50 (ET-50), i.e. the time necessary to reduce cell viability by $50 \%$ was greater than $18 \mathrm{~h}$ and indistinguishable to that observed in naïve cells. Furthermore, no difference in the release of LDH cytoplasmic enzyme was observed between AGMA1-treated and untreated tissues, suggesting that no cytoplasmic damage had occurred. Finally, there was no significant difference in the level of the proinflammatory cytokine IL-1 alpha (Table 3) compared to untreated samples.

\subsection{Assessment of AGMA1 antiviral activity in vivo}

Finally, we sought to confirm our in vitro findings and assess AGMA1 efficacy in vivo by analyzing HSV infection by venereal spread, the chief route of HSV transmission in industrialized and developing countries [11,53]. Here, we used an established murine animal model of HSV genital infection [38] and $100 \mu \mathrm{g} / \mathrm{ml}$ AGMA1, a concentration that was well-tolerated in mice and able to abolish viral infectivity in the EpiVaginal tissue. Tests were aimed to: 1. Determine the best timing of administration before infection; 2 . Evaluate efficacy against HSV-1 and HSV-2 strains; 3. Assess the breadth of antiviral activity toward escalating infectious doses; 4. Investigate whether animals that exhibited no visible signs of infection had subclinical infection. All experiments were performed using 6-12 animals/group, a number suitable for statistical analysis, and lasted about four weeks, i.e. a time sufficient to monitor the complete course of the disease. Depending on infectious dose and ability of immune system to restrain viral spread, infection is usually self-limited, clinically manifests at day 5-6, and disappears within two-three weeks [38]. Clinical signs can be negligible (subclinical or asymptomatic infection), severe and rapidly progressing to paralysis and death, or evolve in a persistent disease 
A
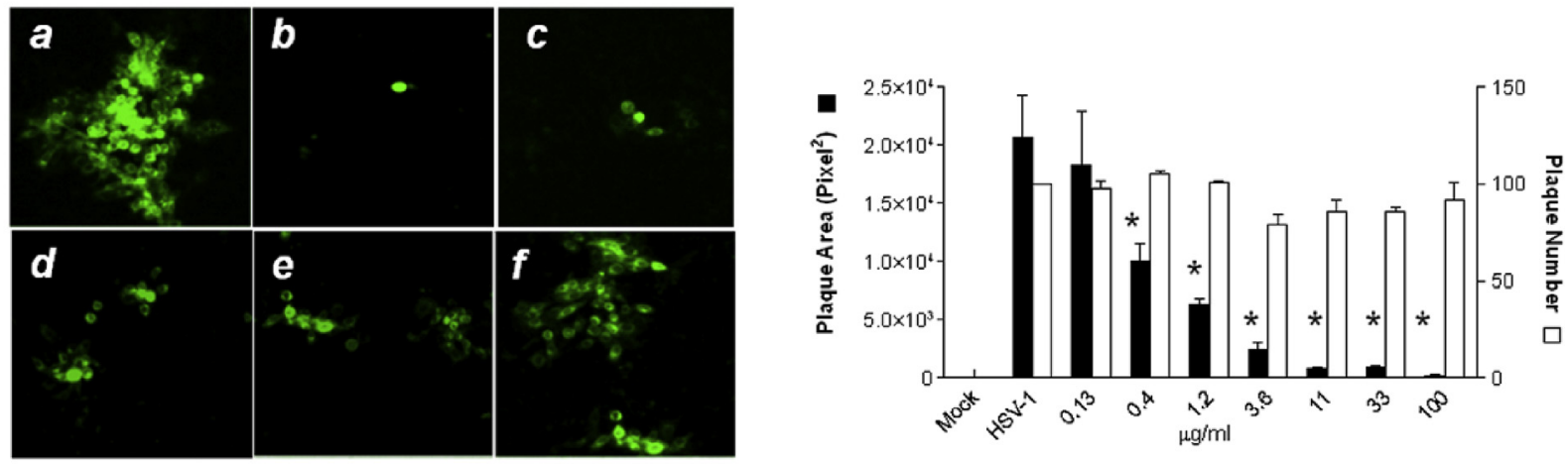

B
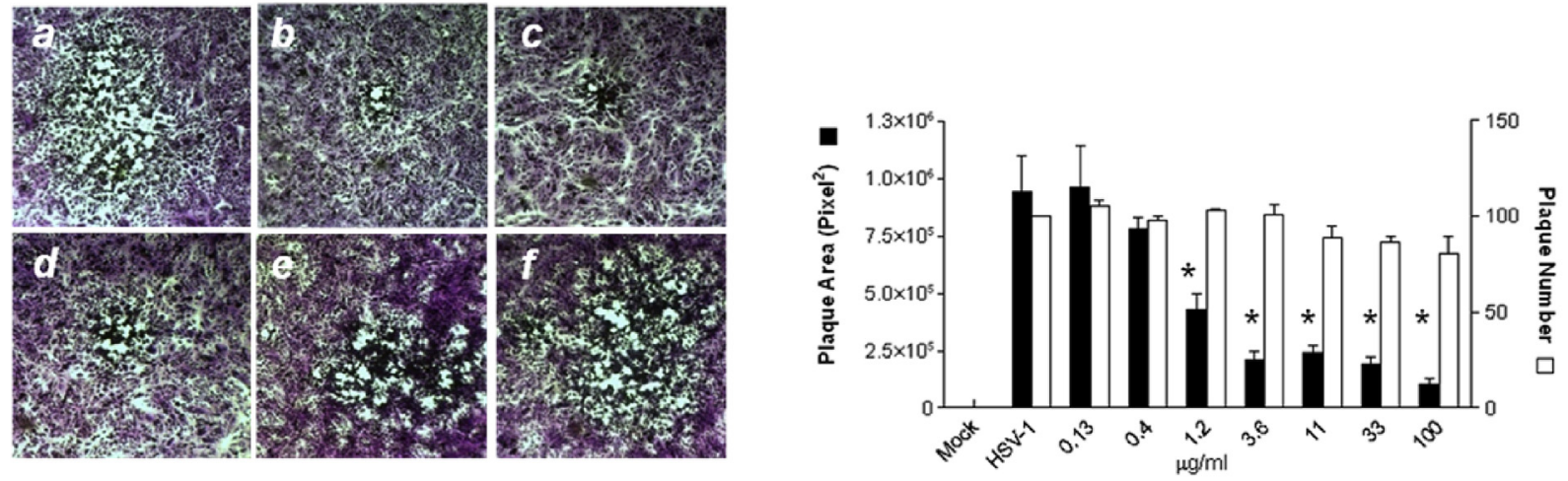

C
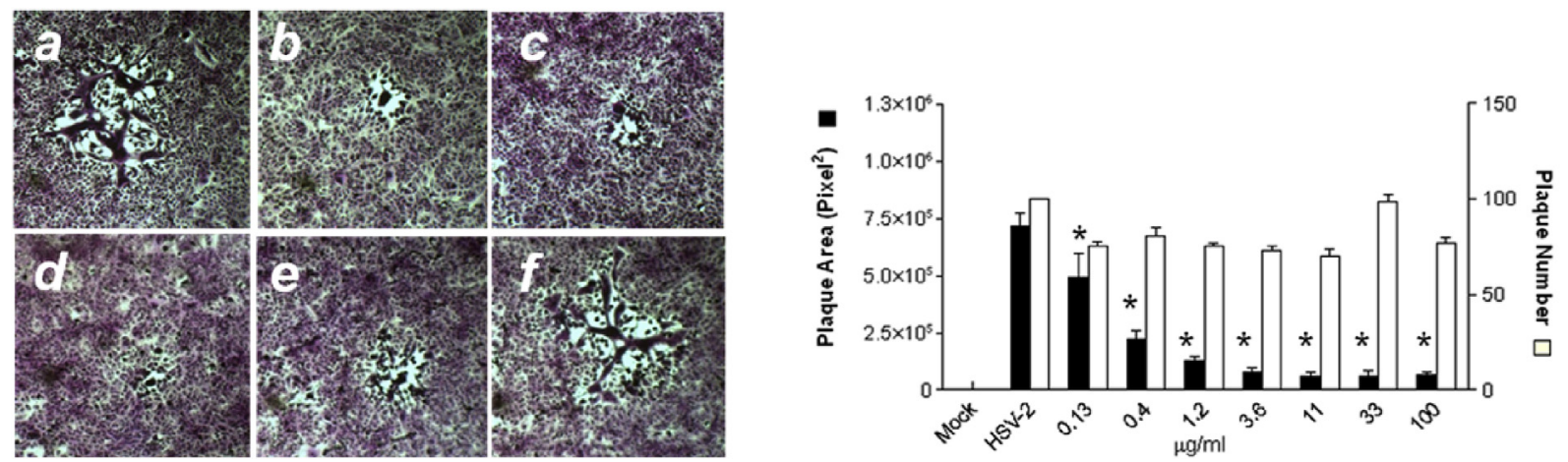

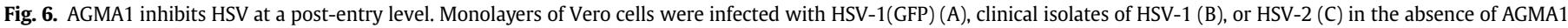

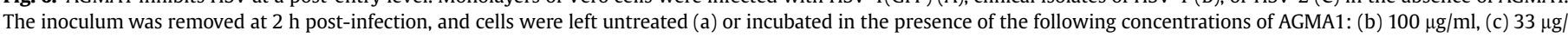

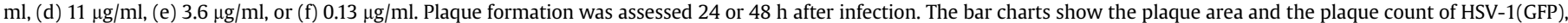
HSV-1 and HSV-2, as a function of AGMA1 concentration. The data presented are means plus standard deviations for triplicates. ${ }^{*} \mathrm{P}<0.05$.

lasting several weeks and usually culminating in the death of the animal. Clinical outcome was scored according to a standard fivepoint scale $[38,47]$ as described in Material and Methods.

The most effective timing of AGMA1 administration was determined using four groups of animals (six animals/group) that were infected via the vagina with $1 \mathrm{LD}_{50}$ of HSV-1 and were either left untreated (naïve control) or treated with AGMA1 $30 \mathrm{~min}, 15 \mathrm{~min}$, or $15 \mathrm{~s}$ before infection. As shown by Fig. 8A, which depicts the percent of animals that remained disease-free throughout the observation period, all naïve controls developed infection, manifesting overt symptoms from day 6 , and two animals died on day $10-11$. Of the 4 surviving animals, 3 had recovered by day 13, and one was still sick when the experiment was terminated. Of the animals treated with AGMA1 30 min before infection, 3 were transiently infected and fully recovered by day 12,1 died on day 9 , and 2 showed no symptoms throughout the course of the follow-up period. In contrast, of the groups of animals pretreated with AGMA1 at $15 \mathrm{~min}$ and $15 \mathrm{~s}$ before infection, 3 and 4 animals remained disease-free, respectively, and 3 and 2 developed a transient and mild disease (clinical score $\leq 2$ ). Although groups were too small to draw firm conclusions, pretreatment at $15 \mathrm{~s}$ and 15 min clearly delayed and reduced clinical manifestations (Fig. 8A). Compared to the naïve group, percent of disease-free animals of these two groups reached statistical significance at day 
A

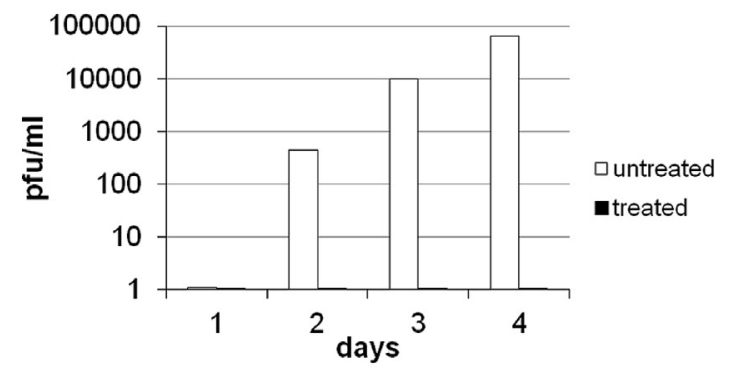

B

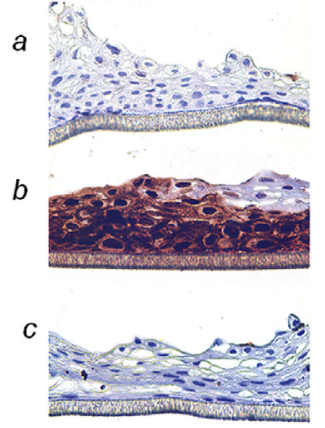

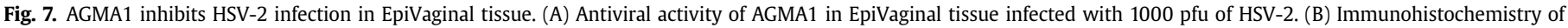

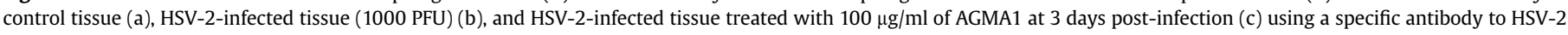

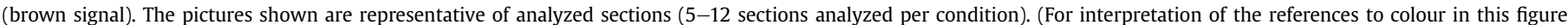
legend, the reader is referred to the web version of this article.)

Table 3

Evaluation of the irritation potential of $100 \mu \mathrm{g} / \mathrm{ml}$ of AGMA1 in the EpiVaginal tissue model.

\begin{tabular}{lllr}
\hline Conditions & \% Viability & LDH release $(A)$ & IL-1 alpha release $(\mathrm{pg} / \mathrm{ml})$ \\
\hline Untreated $(1 \mathrm{~h})$ & 100 & $0.75 \pm 0.06$ & $0.4 \pm 2.1$ \\
AGMA1 $(1 \mathrm{~h})$ & $115.07 \pm 12.90$ & $0.74 \pm 0.02$ & $0.76 \pm 0.03$ \\
Untreated $(4 \mathrm{~h})$ & 100 & $0.73 \pm 0.03$ & 1.9 \\
AGMA1 $(4 \mathrm{~h})$ & $109.59 \pm 0.04$ & $1.80 \pm 0.04$ & $9.9 \pm 1.0$ \\
Untreated $(18 \mathrm{~h})$ & 100 & $1.46 \pm 0.02$ & $31.5 \pm 6.2$ \\
AGMA1 $(18 \mathrm{~h})$ & $67.04 \pm 10.75$ & & $32.9 \pm 1.4$ \\
\hline
\end{tabular}

7 post infection $(p<0.002$, data not shown). This result indicates that AGMA1 exerts similar antiviral activity when applied within this period of time. In all subsequent experiments, we thus applied AGMA1 15 min before infection.

We next assessed whether AGMA1 protects against both HSV-1 and HSV-2 strains. For these experiments we used 36 animals that were split in three groups: naïve, AGMA1, and Vehicle, i.e. animals treated with AGMA1 carrier. After administration of AGMA1 and Vehicle, animal groups were further subdivided into two groups and infected with 1 LD 50 HSV-1 or HSV-2. Five animals of the naïve/ HSV-1 group become overtly infected and 1 showed no symptoms. Of the infected animals, 2 died on day 11 and 3 fully recovered. All naïve/HSV-2 animals acquired infection, 3 died on day 11 and 2 still showed disease symptoms at the end of observation period (Fig. 8B). No significant differences were observed between Vehicle and Naïve groups. AGMA1 reduced the outcome of disease of the two infections. In both AGMA1/HSV-1 and AGMA1/HSV-2 groups, 2 animals showed no symptoms, 3 animals were transiently infected, and 1 animal died. Compared to the naïve group, the difference in numbers of disease-free animals was statistically significant for AGMA1/HSV-2 group ( $p<0.05$ ), this was not the case for HSV-1 as only $5 / 6$ naïve animals became sick and, in general, showed a milder course of infection (Fig. 8B).

Because of similar efficacy against the two strains, higher virulence of HSV-2 strain, higher incidence of genital HSV-2 infections in humans, and to limit in vivo tests, analysis of AGMA1 potency against escalating doses was performed with HSV-2. For this experiment we used 10 animals/group and 1, 10, and, 100 HSV-2 $\mathrm{LD}_{50}$. As expected, clinical grading and mortality rate increased with infectious dose; $1 \mathrm{LD}_{50}$ infected $9 / 10$ and killed 3/10 animals of Naïve group, and infected and killed 9/9 and 5/9 animals of Vehicle group (one animal was found dead at day 2 post infection for unknown reasons); $10 \mathrm{LD}_{50}$ infected all animals of both groups and killed 4/10 and 6/10 animals of Naïve and Vehicle groups, respectively; $100 \mathrm{LD}_{50}$ infected and killed all animals of both groups except 1 naïve that fully recovered at day 18 post infection. The
AGMA1 group challenged with $1 \mathrm{LD}_{50}$ yielded: 5 animals totally protected, 4 mildly and transiently infected, and 1 still sick at the end of observation period. Statistical analysis showed that this group performed significantly better compared to Naïve and Vehicle at $p<0.05$ (Fig. 8C). Pretreatment with AGMA1 and challenging with $10 \mathrm{LD}_{50}$ resulted in 3 animals fully protected, 4 transiently infected, 1 chronically infected, and 1 death. These results were, at same time, significantly different compared to control groups at $p<0.0001$. Finally, AGMA1 pretreatment did not spare animals from infection with $100 \mathrm{LD}_{50}$ but, among the 6 surviving animals, 4 were transiently infected and 2 still sick at the end of the observation period. Whereas the difference in percent disease-free animals reached statistical significance only at onset of disease and end of experiment, this was statistically significant by comparing mortality rate by day 10 post infection $(p<0.01)$ (Fig. 8C and data not shown). This experiment demonstrated that AGMA1 protects against disease at low to moderate infectious doses, and lessens clinical consequences of a very high input dose $\left(100 \mathrm{LD}_{50}\right)$, an infectious load unlikely to find in human transmission.

The last set of in vivo experiments was aimed to assess whether the animals that had no clinical signs underwent subclinical (nearly or completely asymptomatic) infection as it frequently occurs in nature $[53,54]$. To this end, Naïve, Vector, and AGMA1 groups (11 animals/each) were challenged with $10 \mathrm{LD}_{50} \mathrm{HSV}-2$, monitored for four weeks, left untreated for two months, and finally immunosuppressed with a bolus of cyclofosfamide to induce reactivation of latent infection. At four weeks post infection, 4 AGMA1 and 1 naïve mice resisted or underwent subclinical infection; remaining animals were either dead or still sick (Table 4). One AGMA1 mice died at day 3 post infection for unknown reasons as it showed no clinical symptoms. As observed here, as well as in a previous study [38], cyclofosfamide treatment depleted circulating lymphocytes by approximately $90 \%$ within 1 day and left the animals strongly leukopenic for over two weeks (data not shown). Six out of seven naïve animals showed clinical lesions by day 3 post-cyclofosfamide treatment and half of them died between day $6-8$. The naïve 
A
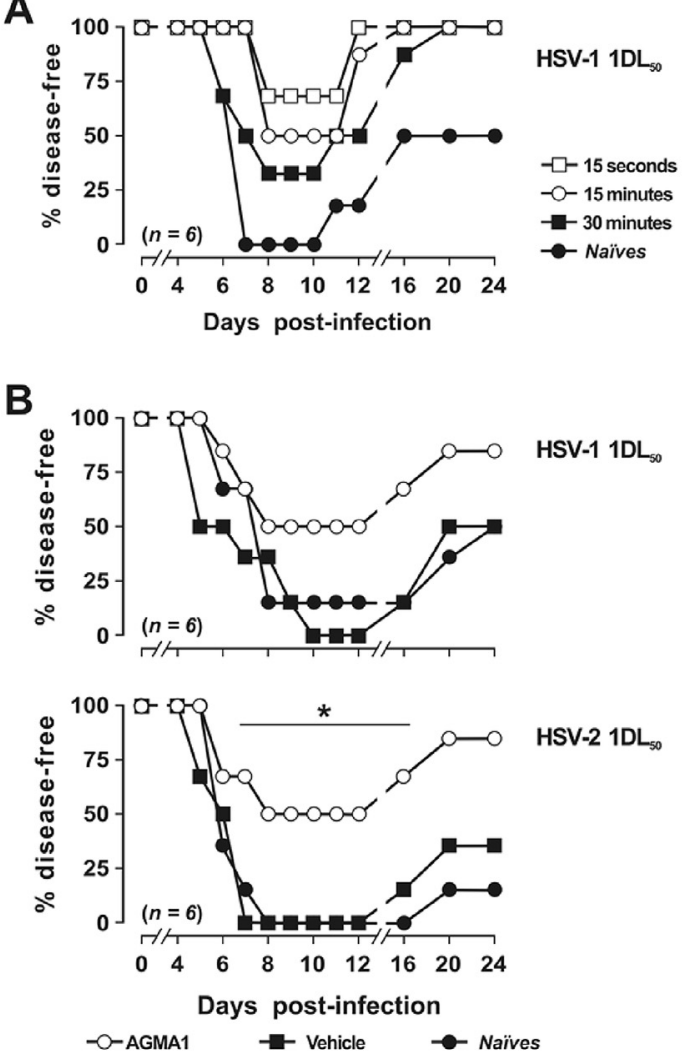

C
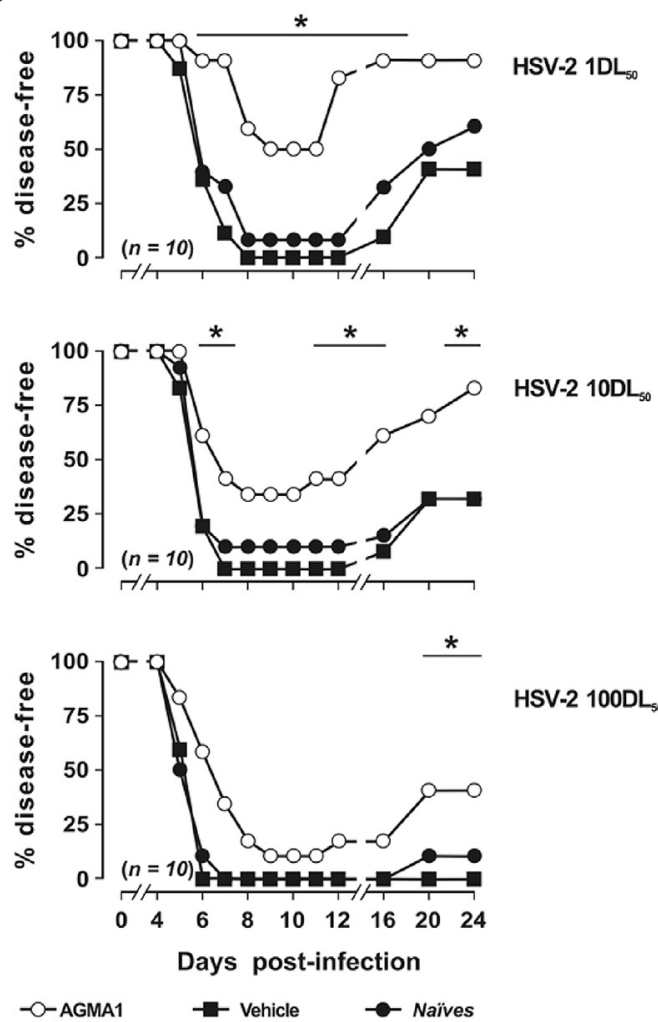

HSV-2 100DL

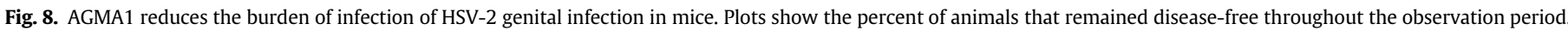

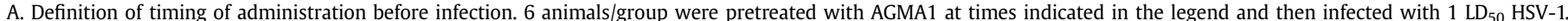

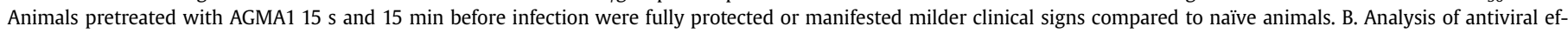

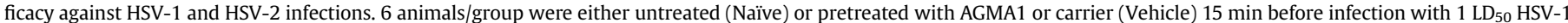

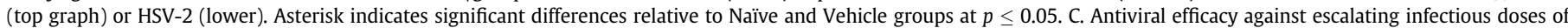

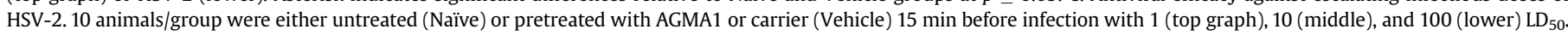
Asterisk indicates significant differences relative to Naïve and Vehicle groups at $p \leq 0.05$.

Table 4

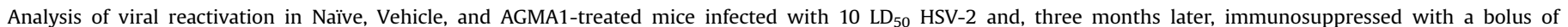
Cyclofosfamide.

\begin{tabular}{|c|c|c|c|c|c|c|c|c|c|}
\hline \multirow[t]{2}{*}{ Animal group } & \multicolumn{4}{|c|}{ Disease status at week 4 post-infection } & \multicolumn{5}{|c|}{ Disease status at week 4 post-immunosuppression } \\
\hline & No. treated & Dead & Sick $^{\mathrm{a}}$ & Healthy $^{\mathrm{b}}$ & No. treated & Dead & Sick & Healthy & $\overline{\text { HSV-2 genome in nervous tissues }}{ }^{\mathrm{c}}$ \\
\hline Naïve & 11 & 4 & 6 & 1 & 7 & 3 & 3 & 1 & $3 / 2$ \\
\hline Vehicle & 11 & 6 & 5 & 0 & 5 & 3 & 2 & 0 & $0 / 0$ \\
\hline AGMA1 & 11 & $3^{d}$ & 4 & 4 & 7 & 1 & 3 & 3 & $5 / 2$ \\
\hline
\end{tabular}

a Animals that were still sick at the end of follow-up or developed transient infection.

b Animals that remained disease-free throughout the follow-up.

c No. examined/no. positive animals for HSV-2 genome. Nested PCR analysis was performed in the sciatic nerve and cervical ganglia collected at week 4 postcyclophosphamide treatment.

${ }^{\mathrm{d}}$ One death was likely unrelated to HSV infection as the animal died at day 3 post-infection and showed no clinical symptoms.

animal that showed no clinical lesions following infection also had no symptoms after immunosuppression, suggesting that this animal resisted infection. Clinical relapse also occurred in 5/5 Vehicle animals, 3 of which died between day 8-11. In the AGMA1 group, 3/ 7 mice that remained disease-free following infection also showed no signs upon immunosuppression; 4/7 mice had clinical relapse that was milder, delayed, and shorter compared to control animals. Of note, three of them were transiently infected and one showed no signs of disease following primary infection (Table 4). At the end of the experiment, animals were sacrificed, and their sciatic nerves and cervical ganglia assayed for HSV-2 genome. All animals that underwent clinical reactivation were PCR positive as opposed to animals that were disease-free after immunosuppression and tested negative (Table 4).

\section{Discussion}

This study reports on the anti-herpetic activity of AGMA1, a prevailingly cationic PAA that exerts antiviral activity with a mode of action that differs from that of acyclovir. Indeed, immunoblotting analysis revealed that AGMA1 blocks infection before the expression of immediate early viral genes, whereas acyclovir prevents late viral genes expression. The antiviral activity of AGMA1 against acyclovir-resistant strains supports this conclusion further. These 
features prompted us to perform further studies in order to explore the therapeutic potential of AGMA1 as an anti-herpetic compound.

Synthetic polycations have recently become the subject of much interest as candidates for the prevention of viral infections. They can inactivate the virus particle directly, as demonstrated for polyethylenimine (PEI) against a panel of viruses, including HSV [44,55-58], and for the poly(acrylic ester) Eudragit E100, hystidine peptides, polylysine, and arginine, all of which are endowed with membrane-destabilizing activity against HSV [59-62]. Although AGMA1 shares a polycationic nature with the above mentioned compounds, here we demonstrate that it does not inactivate the virus particles. The lack of a direct effect of AGMA1 on the virus and its capacity to inhibit the expression of immediate-early viral proteins suggest that AGMA1 could act directly on target cells by interfering with a very early event in HSV infection, possibly corresponding to virus attachment and/or entry. Indeed, our results demonstrate that AGMA1 prevents HSV-1 and HSV-2 attachment. Attachment assays showed that AGMA1 treatment prevents viral particles from binding to the cell surface; this was further demonstrated by immunoblotting the lysates from treated cells. The initial interaction between HSV and the cell membrane is mediated by interactions between the positively charged domains on viral glycoproteins $\mathrm{gC}$ and $\mathrm{gB}$ and the negatively charged HSPGs on the target cell membrane [63]. Others findings have revealed that AGMA1 acts by binding to virus receptors on the surface of target cells [36]. Of note, we have previously reported that AGMA1 exerts antiviral activity against other HSPG-dependent viruses [28]. Moreover, we have previously shown that, due to its polycationic nature, AGMA1 is endowed with heparin-binding capacity and, accordingly, tethers to HSPGs present on the surface of different epithelial cell types, thereby masking these receptors and preventing HPV attachment [36]. Indeed, the data reported in this study demonstrate that AGMA1 binds to Vero cells in a HSPGdependent manner. However, they do not rule out other interactions occurring between AGMA1 and the cell surface. To this regard, it is important to point out that the side guanidine groups of AGMA1 might reinforce membrane interactions, thanks to their well-known chaotropic properties [28,36,64]. Interestingly are also the observation that the binding of HSV-1 and 2 glycoproteins gD to nectin- 1 depends on several basic amino acids, including L25, R36, R134 and R222 [65] and that HSV-2 infection can be mediated by $\alpha_{\mathrm{v}} \beta_{3}$ integrin [66] that is well known to bind its physiological or pathological ligand via basic domains [67-69]. Taken together these data suggest that the high positive charge of AGMA1 may mediate its binding to receptors different from HSPGs, conferring to the polymer a "multitarget" mechanism of action, as already demonstrated for cationic dendrimer-like compounds [70].

An important feature of the AGMA1 antiviral activity that most probably derives from its capacity to bind to and mask HSPGs, thus preventing virus interaction, is its ability to diminish a cell's susceptibility to HSV when administered before virus infection. By contrast, we show that heparin, a known attachment inhibitor that interacts directly with the virus particle rather than with the cells, did not show any inhibitory activity in the pre-treatment assay.

This feature prompted us to focus our studies on AGMA1 as a potential microbicide for the prevention of the sexual transmission of HSV infections.

The development of effective, safe, and topically applied microbicides is an apt strategy to prevent STIs that cannot be contained with pre-exposure immunization strategies or systemic antiviral treatments.

The lack of a protective vaccine against HSV, the observation that genital herpes increases susceptibility to HIV and other STIs $[8,71]$, and the inherent ability of herpesviruses to establish latent infections underline the importance of topical microbicides to block HSV mucosal transmission by inhibiting virus attachment [72].

In recent years, numerous preclinical studies have been performed mainly focused on negatively charged polyanions able to bind to the viral envelope and block attachment, but none of these compounds have passed phase III clinical trials [16,17]. Many dendrimers have been screened for potential antiviral activity and selected for development as candidate microbicides [18-20].

Beside the already mentioned cationic dendrimers whose main mechanism of action is by binding and masking HSPGs to virus attachment (see introduction), other compounds have been developed among which the polyanionic sulfonated and carboxylated polylysine dendrimers, shown to exhibit inhibitory activity against HSV-1 and -2 infection in vitro and in vivo and protecting animals against an intravaginal HSV-2 challenge [19].

Accordingly, SPL7013, a dendrimer with highly anionic charged branches, has been developed by Starpharma Pty Ltd (Melbourne, Australia) as microbicide against vaginal bacteriosis (marketed as VivaGel) is currently under Phase 3 testing for its capacity to prevent HIV and HSV infections [20,21].

Unlike these previous studies, we recommend a cationic PAA AGMA1 - for further development as an active ingredient of topical microbicides due to several important properties. First, AGMA1 shows antiviral activity in an organotypic model of cervicovaginal epithelial tissue, i.e. the main target of HSV-2 infection. In this system, a total inhibition of HSV, emerging from the apical surface, was observed at different days post infection.

A second important property of AGMA1 is that, despite being positively charged and in contrast with other polycationics (e.g. $\mathrm{PEI}$ ) it is not toxic, it is not hemolytic in the $\mathrm{pH}$ range 5.5-7.4 [22], and it does not lead to an inflammatory response in the tissue model. Third, when it was administered two hours pre-infection, AGMA1 prevented infection in Epivaginal tissues, as observed in vitro. Fourth, AGMA1 did not affect the growth of Lactobacillus gasseri and Lactobacillus acidophilus, two components of the normal vaginal flora (data not shown). Fifth, AGMA1 antiviral activity was not affected by acidic treatments ( $\mathrm{pH} 3$ and $\mathrm{pH} 5$ ), that simulate physiological vaginal environment.

Finally, it must be pointed out that severe HIV infection-driven immunodeficiency causes a well documented increase in HSV as well as HPV infection [73,74]. Conversely, HSV-2 infection clearly enhances the transmission of HIV-1 infection [8]. Relevant to this point, AGMA1 has been already demonstrated to prevent HPV infection suggesting the possibility to obtain a formulation with a multitarget mechanism of action that can control and/or prevent multiple sexually transmitted infections simultaneously.

The in vitro results prompted us to test AGMA1 as a topical microbicide against genital HSV infection in vivo. For this task we used two virulent isolates shown to be difficult to contain by immunological means [38], a well-validated animal model, and a clinical scoring largely used for HSV genital infection [47]. AGMA1 showed some antiviral efficacy even when applied 30 min before infection, a time lapse that compares favorably with other chemical compounds for which antiviral activity has been shown to fade very rapidly [75]. All in vivo tests were carried out by applying AGMA1 15 min before infection, which was performed with high input loads of HSV-1 and HSV-2. AGMA1 significantly reduced infection rate and clinical grading even against $10 \mathrm{LD}_{50} \mathrm{HSV}-2$, an infectious dose that induced severe disease and high mortality rate in controls. Finally, at 100 LD 50 , which killed 19/20 controls, AGMA1 reduced casualty to $4 / 10$ animals and the 6 surviving animals infection healed in three weeks. Since herpetic infections establish life-long persistency in the host, a crucial matter is viral reactivation upon appropriated stimuli. This was addressed in animals that partially or apparently resisted initial infection. Here, animals 
were treated with a potent chemotherapeutic drug that reactivated HSV-2 infection in 92\% controls versus 57\% AGMA1-treated animals. Further, clinical relapse in the latter group was milder and transient suggesting that AGMA1 reduces the number of latently infected cells and the potential for virus reactivation. In all, in vivo tests indicate that AGMA1 provides significant protection against HSV infection and disease and compares favorably well with dendrimers and polyanions considered good candidate topical microbicides [18-21,34,58,75,76].

\section{Future study}

The main aim of this work was the evaluation of the activity and toxicity of AGMA1. Considering the efficacy and safety results obtained, the next step of the research will concern the development of an improved AGMA1 preparation intended for vaginal administration as a microbicide. Formulation considerations and product design will considered the regulatory aspects and will mainly comprise the choice of excipients, the buffer capacity, the viscosity, the stability and the shelf-life as well as the volume to be administered. The rheological properties and the vaginal distribution will be also evaluated to obtain a desiderable microbicide product.

\section{Conclusion}

AGMA1 prevents HSV infection in vitro, ex vivo and in vivo and shows a good biocompatibility profile. Of consequence, AGMA1 is a highly promising candidate for development as a topical microbicide for the prevention of sexually transmitted HSV and HPV infections. Further studies and the validation of the product in a pharmaceutical formulation will be required to advance it for clinical testing.

\section{Acknowledgments}

This work was supported by a grant from Ricerca Locale Finanziata dall'Università degli Studi di Torino (ex 60\%) 2012 to D.L.

\section{References}

[1] K.J. Lookerand, G.P. Garnett, A systematic review of the epidemiology and interaction of herpes simplex virus types 1 and 2, Sex. Transm. Infect. 81 (2005) 103-107.

[2] A.L. Cunningham, R.J. Diefenbach, M. Miranda-Saksena, L. Bosnjak, M. Kim, C. Jones, M.W. Douglas, The cycle of human herpes simplex virus infection: virus transport and immune control, J. Infect. Dis. 194 (2006) S11-S18.

[3] B. Roizman, D.M. Knipe, R.J. Whitley, Herpes simplex viruses, in: fifth ed., in: D.M. Knipe, et al. (Eds.), Fields virology, vol. 2, Lippincott, Williams \& Wilkins, Philadelphia, PA, 2007, pp. 2501-2601.

[4] F. Xu, M.R. Sternberg, B.J. Kottiri, G.M. McQuillan, F.K. Lee, A.J. Nahmias, S.M. Berman, L.E. Markowitz, Trends in herpes simplex virus type 1 and type 2 seroprevalence in the United States, JAMA 296 (2006) 964-973.

[5] A. Wald, K. Link, Risk of human immunodeficiency virus infection in herpes simplex virus type 2-seropositive persons: a meta-analysis, J. Infect. Dis. 185 (2002) 45-52.

[6] D.J. Carr, L. Tomanek, Herpes simplex virus and the chemokines that mediate the inflammation, Curr. Top. Microbiol. Immunol. 303 (2006) 47-65.

[7] L. Corey, Herpes simplex virus type 2 and HIV-1: the dialogue between the 2 organisms continues, J. Infect. Dis. 195 (2007) 1242-1244.

[8] E.E. Freeman, H.A. Weiss, J.R. Glynn, P.L. Cross, J.A. Whitworth, R.J. Hayes, Herpes simplex virus 2 infection increases HIV acquisition in men and women: systematic review and meta-analysis of longitudinal studies, AIDS 20 (2006) 73-83.

[9] Z. Feng, Z. Qiu, Z. Sang, C. Lorenzo, J. Glasser, Modeling the synergy between HSV-2 and HIV and potential impact of HSV-2 therapy, Math. Biosci. 245 (2013) 171-187.

[10] L. Corey, A. Wald, C.L. Celum, T.C. Quinn, The effects of herpes simplex virus-2 on HIV-1 acquisition and transmission: a review of two overlapping epidemics, J. Acquir Immune Defic. Syndr. 35 (2004) 435-445.

[11] A.R. Thurman, G.F. Doncel, Herpes simplex virus and HIV: genital infection synergy and novel approaches to dual prevention, Int. J. STD AIDS 23 (2012) 613-619.
[12] M. Ghebremichael, D. Habtzgi, E. Paintsil, Deciphering the epidemic synergy of herpes simplex virus type 2 (HSV-2) on human immunodeficiency virus type 1 (HIV-1) infection among women in sub-Saharan Africa, BMC Res. Notes 5 (2012) 451.

[13] D.W. Kimberlin, R.J. Whitley, Antiviral therapy of HSV-1 and -2, in: A. Arvin, G. Campadelli-Fiume, E. Mocarski, P.S. Moore, B. Roizman, R. Whitley, K. Yamanishi (Eds.), Human Herpesviruses: Biology, Therapy, and Immunoprophylaxis, Cambridge University Press, Cambridge, 2007. Chapter 6.

[14] http://www.who.int/immunization/research/meetings_workshops/HSV vaccineRD_Sept2014.pdf.

[15] C. Celum, R.A. Morrow, D. Donnell, T. Hong, C.W. Hendrix, K.K. Thomas, K.H. Fife, E. Nakku-Joloba, A. Mujugira, J.M. Baeten, Partners PrEP Study Team, Daily oral tenofovir and emtricitabinetenofovir preexposure prophylaxis reduces herpes simplex virus type 2acquisition among heterosexual HIV-1uninfected men and women:a subgroup analysis of a randomized trial, Ann. Intern. Med. 161 (2014 Jul 1) 11-19.

[16] M. Rusnati, E. Vicenzi, M. Donalisio, P. Oreste, S. Landolfo, D. Lembo, Sulfated K5 Escherichia coli polysaccharide derivatives: a novel class of candidate antiviral microbicides, Pharmacol. Ther. 123 (2009) 310-322.

[17] K. Honey, Microbicide trial screeches to a halt, J. Clin. Investig. 117 (2007) 1116.

[18] A. Rosa Borges, C.L. Schengrund, Dendrimers and antivirals: a review, Curr Drug Targets Infect. Disord. 5 (2005) 247-254.

[19] D.I. Bernstein, L.R. Stanberry, S. Sacks, N.K. Ayisi, Y.H. Gong, J. Ireland R.J. Mumper, G. Holan, B. Matthews, T. McCarthy, N. Bourne, Evaluation of unformulated and formulated dendrimer-based microbicide candidates in mouse and guinea pig models of genital herpes, Antimicrob. Agents Chemother. 47 (2003) 3784-3788.

[20] R. Rupp, S.L. Rosenthal, L.R. Stanberry, VivaGel (SPL7013 Gel): a candidate dendrimer-microbicide for the prevention of HIV and HSV infection, Int. J. Nanomed. 2 (2007) 561-566.

[21] C.F. Price, D. Tyssen, S. Sonza, A. Davie, S. Evans, G.R. Lewis, S. Xia, T. Spelman, P. Hodsman, T.R. Moench, A. Humberstone, J.R. Paull, G. Tachedjian, SPL7013 Gel (VivaGel ${ }^{\mathbb{B}}$ ) retains potent HIV-1 and HSV-2 inhibitory activity following vaginal administration in humans, PLoS One 6 (2011) e24095.

[22] P. Ferruti, Poly(amidoamine)s: past, present, and perspectives, J. Polym. Sci. A Polym. Chem. 51 (2013) 2319-2353.

[23] S. Richardson, P. Ferruti, R. Duncan, Poly(amidoamine)s as potential endosomolytic polymers: evaluation in vitro and body distribution in normal and tumour-bearing animals, J. Drug Target 6 (1999) 391-404.

[24] E. Ranucci, G. Spagnoli, P. Ferruti, D. Sgouras, R. Duncan, Poly(amidoamine)s with potential as drug carriers: degradation and cellular toxicity, J. Biomater. Sci. Polym. Ed. 2 (1991) 303-315.

[25] J. Franchini, E. Ranucci, P. Ferruti, M. Rossi, R. Cavalli, Synthesis, physicochemical properties, and preliminary biological characterizations of a nove amphoteric agmatine-based poly(amidoamine) with RGD-like repeating units, Biomacromolecules 7 (2006) 1215-1222.

[26] P. Ferruti, J. Franchini, M. Bencini, E. Ranucci, G.P. Zara, L. Serpe, L. Primo, R. Cavalli, Prevailingly cationic agmatine-based amphoteric polyamidoamine as a nontoxic, nonhemolytic, and "stealthlike" DNA complexing agent and transfection promoter, Biomacromolecules 8 (2007) 1498-1504.

[27] R. Cavalli, A. Bisazza, R. Sessa, L. Primo, F. Fenili, A. Manfredi, E. Ranucci, P. Ferruti, Amphoteric agmatine containing polyamidoamines as carriers for plasmid DNA in vitro and in vivo delivery, Biomacromolecules 11 (2010) 2667-2674.

[28] M. Donalisio, E. Ranucci, V. Cagno, A. Civra, A. Manfredi, R. Cavalli, P. Ferruti D. Lembo, Agmatine-containing poly(amidoamine)s as novel class of antiviral macromolecules: structural properties and in vitro evaluation of infectivity inhibition, Antimicrob. Agents Chemother. 58 (2014) 6315-6319.

[29] D. Shukla, P.G. Spear, Herpesviruses and heparan sulfate: an intimate relationship in aid of viral entry, J. Clin. Investig. 108 (2001) 503-510.

[30] L. Bousarghin, A. Touze, L. Combita-Rojas, P. Coursaget, Positively charged sequences of human papillomavirus type 16 capsid proteins are sufficient to mediate gene transfer into target cells via the heparan sulfate receptor, J. Gen. Virol. 84 (2003) 157-164.

[31] M. Szewczyk, J. Drzewinska, V. Dzmitruk, D. Shcharbin, B. Klajnert, D. Appelhans, M. Bryszewska, Stability of dendriplexes formed by anti-HIV genetic material and poly(propylene imine) dendrimers in the presence of glucosaminoglycans, J. Phys. Chem. B 116 (2012) 14525-14532.

[32] A. Luganini, A. Giuliani, G. Pirri, L. Pizzuto, S. Landolfo, G. Gribaudo, Peptidederivatized dendrimers inhibit human cytomegalovirus infection by blocking virus binding to cell surface heparan sulfate, Antivir. Res. 85 (2010) 532-540.

[33] M. Donalisio, M. Rusnati, A. Civra, A. Bugatti, D. Allemand, G. Pirri, A. Giuliani, S. Landolfo, D. Lembo, Identification of a dendrimeric heparan sulfate-binding peptide that inhibits infectivity of genital types of human papillomaviruses, Antimicrob. Agents Chemother. 54 (2010) 4290-4299.

[34] A. Luganini, S.F. Nicoletto, L. Pizzuto, G. Pirri, A. Giuliani, S. Landolfo, G. Gribaudo, Inhibition of herpes simplex virus type 1 and type 2 infections by peptide-derivatized dendrimers, Antimicrob. Agents Chemother. 55 (2011) 3231-3239.

[35] I. Bon, D. Lembo, M. Rusnati, A. Clò, S. Morini, A. Miserocchi, A. Bugatti S. Grigolon, G. Musumeci, S. Landolfo, M.C. Re, D. Gibellini, Peptide-derivatized SB105-A10 dendrimer inhibits the infectivity of R5 and X4 HIV-1 strains in primary PBMCs and cervicovaginal histocultures, PLoS One 8 (2013) e76482. 
[36] V. Cagno, M. Donalisio, A. Bugatti, A. Civra, R. Cavalli, E. Ranucci, P. Ferruti, M. Rusnati, D. Lembo, The agmatine-containing poly(amidoamine) polymer AGMA1 binds cell surface heparan sulfates and prevents the attachment of mucosal human papillomaviruses, Antimicrob. Agents Chemother. 59 (2015) $5250-5259$.

[37] M. Tognon, R. Manservigi, A. Sebastiani, G. Bragliani, M. Busin, E. Cassai, Analysis of HSV isolated from patients with unilateral and bilateral herpetic keratitis, Int. Ophthalmol. 8 (1985) 13-18.

[38] F.L. Chiuppesi, L. Vannucci, A. De Luca, M. Lai, B. Matteoli, G. Freer, R. Manservigi, L. Ceccherini-Nelli, F. Maggi, M. Bendinelli, M. Pistello, A lentiviral vector-based, herpes simplex virus 1 (HSV-1) glycoprotein B vaccine affords cross-protection against HSV-1 and HSV-2 genital infections, J. Virol. 86 (2012) 6563-6574.

[39] A.G. Teepe, L.B. Allen, R.J. Wordinger, E.F. Harris, Effect of the estrous cycle on susceptibility of female mice to intravaginal inoculation of herpes simplex virus type 2 (HSV-2), Antivir. Res. 14 (1990) 227-235.

[40] S. Ernst, R. Langer, C.L. Cooney, R. Sasisekharan, Enzymatic degradation of glycosaminoglycans, Crit. Rev. Biochem. Mol. Biol. 30 (1995) 387-444.

[41] C. Urbinati, A. Bugatti, P. Oreste, G. Zoppetti, J. Waltenberger, S. Mitola, D. Ribatti, M. Presta, M. Rusnati, Chemically sulfated Escherichia coli K5 polysaccharide derivatives selectively inhibits HIV-1 Tat biological activities in vitro and in vivo", FEBS Lett. 568 (2004) 171-177.

[42] D. Lembo, M. Donalisio, A. Hofer, M. Cornaglia, W. Brune, U. Koszinowski, L. Thelander, S. Landolfo, The ribonucleotide reductase R1 homolog of murine cytomegalovirus is not a functional enzyme subunit but is required for pathogenesis, J. Virol. 78 (2004) 4278-4288.

[43] B. Shogan, L. Kruse, G.B. Mulamba, A. Hu, D.M. Coen, Virucidal activity of a GTrich oligonucleotide against herpes simplex virus mediated by glycoprotein B, J. Virol. 80 (2006) 4740-4747.

[44] G.A. Spoden, K. Besold, S. Krauter, B. Plachter, N. Hanik, A.F. Kilbinger, C. Lambert, L. Florin, Polyethylenimine is a strong inhibitor of human papillomavirus and cytomegalovirus infection, Antimicrob. Agents Chemother. 56 (2012) 75-82.

[45] E. Gong, B. Matthews, T. McCarthy, J. Chu, G. Holan, J. Raff, S. Sacks, Evaluation of dendrimer SPL7013, a lead microbicide candidate against herpes simplex viruses, Antivir. Res. 68 (2005) 139-146.

[46] R. Cavalli, M. Donalisio, A. Bisazza, A. Civra, E. Ranucci, P. Ferruti, D. Lembo, Enhanced antiviral activity of acyclovir loaded into nanoparticles, Methods Enzymol. 509 (2012) 1-19.

[47] D. Palliser, D. Chowdhury, Q.Y. Wang, S.J. Lee, R.T. Bronson, D.M. Knipe, J. Lieberman, An siRNA-based microbicide protects mice from lethal herpes simplex virus 2 infection, Nature 439 (2006) 89-94.

[48] P. Coyle, A. Desai, D. Wyatt, C. McCaughey, H. O'Neill, A comparison of virus isolation, indirect immunofluorescence and nested multiplex polymerase chain reaction for the diagnosis of primary and recurrent herpes simplex type 1 and type 2 infections, J. Virol. Methods 83 (1999) 75-82.

[49] P.G. Spear, M.T. Shieh, B.C. Herold, D. WuDunn, T.I. Koshy, Heparan sulfate glycosaminoglycans as primary cell surface receptors for herpes simplex virus, Adv. Exp. Med. Biol. 313 (1992) 341-353.

[50] K. Nyberg, M. Ekblad, T. Bergström, C. Freeman, C.R. Parish, V. Ferro, E. Trybala, The low molecular weight heparan sulfate-mimetic, PI-88, inhibits cell-to-cell spread of herpes simplex virus, Antivir. Res. 63 (2004) 15-24.

[51] G.A. Karasneh, M. Ali, D. Shukla, An important role for syndecan-1 in herpes simplex virus type-1 induced cell-to-cell fusion and virus spread, PLoS One 6 (2011) e25252.

[52] M. Donalisio, M. Rusnati, V. Cagno, A. Civra, A. Bugatti, A. Giuliani, G. Pirri, M. Volante, M. Papotti, S. Landolfo, D. Lembo, Inhibition of human respiratory syncytial virus infectivity by a dendrimeric heparan sulfate-binding peptide, Antimicrob. Agents Chemother. 56 (2012) 5278-5288.

[53] H. Shin, A. Iwasaki, Generating protective immunity against genital herpes, Trends Immunol. 34 (2013) 487-494.

[54] J.T. Schiffer, L. Corey, Rapid host immune response and viral dynamics in herpes simplex virus-2 infection, Nat. Med. 19 (2013) 280-290.

[55] J. Haldar, J. Chen, T.M. Tumpey, L.V. Gubareva, A.M. Klibanov, Hydrophobic polycationic coatings inactivate wild-type and zanamivir- and/or oseltamivirresistant human and avian influenza viruses, Biotechnol. Lett. 30 (2008) 475-479.

[56] A.M. Larson, H.S. Oh, D.M. Knipe, A.M. Klibanov, Decreasing herpes simplex viral infectivity in solution by surface-immobilized and suspended $\mathrm{N}, \mathrm{N}$ dodecyl,methyl-polyethylenimine, Pharm. Res. 30 (2013) 25-31.

[57] Y. Maitani, K. Ishigaki, Y. Nakazawa, D. Aragane, T. Akimoto, M. Iwamizu,
T. Kai, K. Hayashi, Polyethylenimine combined with liposomes and with decreased numbers of primary amine residues strongly enhanced therapeutic antiviral efficiency against herpes simplex virus type 2 in a mouse model, J. Control Release 66 (2013) 139-146.

[58] K. Hayashi, H. Onoue, K. Sasaki, J.B. Lee, P.K. Kumar, S.C. Gopinath, Y. Maitani, T. Kai, T. Hayashi, Topical application of polyethylenimine as a candidate for novel prophylactic therapeutics against genital herpes caused by herpes simplex virus, Arch. Virol. 159 (2014) 425-435.

[59] R.V. Alasino, I.D. Bianco, M.S. Vitali, J.A. Zarzur, D.M. Beltramo, Characterization of the inhibition of enveloped virus infectivity by the cationic acrylate polymer eudragit E100, Macromol. Biosci. 7 (2007) 1132-1138.

[60] J.J. Docherty, J.J. Pollock, Inactivation of herpes simplex virus types 1 and 2 by synthetic histidine peptides, Antimicrob. Agents Chemother. 31 (1987) 1562-1566.

[61] N. Langeland, L.J. Moore, H. Holmsen, L. Haarr, Interaction of polylysine with the cellular receptor for herpes simplex virus type 1, J. Gen. Virol. 69 (1988) 1137-1145.

[62] K. Tsujimoto, M. Uozaki, K. Ikeda, H. Yamazaki, H. Utsunomiya, M. Ichinose, A.H. Koyama, T. Arakawa, Solvent-induced virus inactivation by acidic arginine solution, Int. J. Mol. Med. 25 (2010) 433-437.

[63] G. Campadelli-Fiume, M. Amasio, E. Avitabile, A. Cerretani, C. Forghieri, T. Gianni, L. Menotti, The multipartite system that mediates entry of herpes simplex virus into the cell, Rev. Med. Virol. 17 (2007) 313-326.

[64] J.K. Myers, C.N. Pace, J.M. Scholtz, Denaturant m values and heat capacity changes: relation to changes in accessible surface areas of protein unfolding, Protein Sci. 4 (1995) 2138-2148.

[65] G. Lu, N. Zhang, J. Oi, Y. Li, Z. Chen, C. Zheng, G.F. Gao, J. Yan, Crystal structure of herpes simplex virus $2 \mathrm{gD}$ bound to nectin- 1 reveals a conserved mode of receptor recognition, J. Virol. 88 (2014) 13678-13688.

[66] N. Cheshenko, J.B. Trepanier, P.A. González, E.A. Eugenin, W.R. Jacobs Jr. B.C. Herold, Herpes simplex virus type 2 glycoprotein $H$ interacts with integrin $\alpha v \beta 3$ to facilitate viral entry and calcium signaling in human genital tract epithelial cells, J. Virol. 88 (2014) 10026-10038.

[67] K.R. Gehlsen, P. Sriramarao, L.T. Furcht, A.P. Skubitz, A synthetic peptide derived from the carboxy terminus of the laminin A chain represents a binding site for the alpha 3 beta 1 integrin, J. Cell Biol. 117 (1992) 449-459.

[68] S. Mitola, R. Soldi, I. Zanon, L. Barra, M.I. Gutierrez, B. Berkhout, M. Giacca, F. Bussolino, Identification of specific molecular structures of human immunodeficiency virus type 1 Tat relevant for its biological effects on vascular endothelial cells, J. Virol. 74 (2000) 344-353.

[69] B.E. Vogel, S.J. Lee, A. Hildebrand, W. Craig, M.D. Pierschbacher, F. Wong-Staal, E. Ruoslahti, A novel integrin specificity exemplified by binding of the alpha $\mathrm{V}$ beta 5 integrin to the basic domain of the HIV Tat protein and vitronectin, J. Cell Biol. 121 (1993) 461-468.

[70] A. Bugatti, P. Chiodelli, J. Rosenbluh, A. Loyter, M. Rusnati, BSA conjugates bearing multiple copies of the basic domain of HIV-1 Tat: prototype for the development of multitarget inhibitors of extracellular Tat, Antivir. Res. 87 (2010) 30-39.

[71] R.V. Barnabas, J.M. Baeten, J.R. Lingappa, K.K. Thomas, J.P. Hughes, N.R. Mugo, S. Delany-Moretlwe, G. Gray, H. Rees, A. Mujugira, A. Ronald, W. Stevens, S. Kapiga, A. Wald, C. Celum, Partners in prevention HSV/HIV transmission study team. Acyclovir prophylaxis reduces the incidence of herpes zoster among HIV-infected individuals: results of a randomized clinical trial, J. Infect. Dis. 213 (2016) 551-555 pii: jiv318.

[72] M.M. Lederman, R. Jump, H.A. Pilch-Cooper, M. Root, S.F. Sieg, Topical application of entry inhibitors as "virustats" to prevent sexual transmission of HIV infection, Retrovirology 5 (2008) 116.

[73] B.J. McGrath, C.L. Newman, Genital herpes simplex infections in patients with the acquired immunodeficiency syndrome, Pharmacotherapy 14 (1994) 529-542.

[74] I. Heard, J.M. Palefsky, M.D. Kazatchkine, The impact of HIV antiviral therapy on human papillomavirus (HPV) infections and HPV-related diseases, Antivir. Ther. 9 (2004) 13-22.

[75] J.A. Fernández-Romero, N. Teleshova, T.M. Zydowsky, M. Robbiani, Preclinical assessments of vaginal microbicide candidate safety and efficacy, Adv. Drug Deliv. Rev. 92 (2014) 27-38.

[76] N. Bourne, L.R. Stanberry, E.R. Kern, G. Holan, B. Matthews, D.I. Bernstein, Dendrimers, a new class of candidate topical microbicides with activity against herpes simplex virus infection, Antimicrob. Agents Chemother. 44 (2000) 2471-2474. 